OECD Economics Department Working Papers No. 1551

Enhancing the social integration of Roma in Slovak Republic

\section{Michaela Bednarik,}

Slavomir Hidas,

Gabriel Machlica 


\section{ENHANCING THE SOCIAL INTEGRATION OF ROMA IN SLOVAK} REPUBLIC

\section{ECONOMICS DEPARTMENT WORKING PAPERS No. 1551}

\section{By Michaela Bednarik, Slavomir Hidas and Gabriel Machlica}

OECD Working Papers should not be reported as representing the official views of the OECD or of its member countries. The opinions expressed and arguments employed are those of the author(s).

Authorised for publication by Isabell Koske, Deputy Director, Country Studies Branch, Economics Department.

All Economics Department Working Papers are available at www.oecd.org/eco/workingpapers.

JT03447767 
OECD Working Papers should not be reported as representing the official views of the OECD or of its member countries. The opinions expressed and arguments employed are those of the author(s).

Working Papers describe preliminary results or research in progress by the author(s) and are published to stimulate discussion on a broad range of issues on which the OECD works.

Comments on Working Papers are welcomed, and may be sent to OECD Economics Department, 2 rue André Pascal, 75775 Paris Cedex 16, France, or by e-mail to eco.contact@oecd.org.

All Economics Department Working Papers are available at www.oecd.org/eco/workingpapers.

This document and any map included herein are without prejudice to the status of or sovereignty over any territory, to the delimitation of international frontiers and boundaries and to the name of any territory, city or area.

The statistical data for Israel are supplied by and under the responsibility of the relevant Israeli authorities. The use of such data by the OECD is without prejudice to the status of the Golan Heights, East Jerusalem and Israeli settlements in the West Bank under the terms of international law.

On 25 May 2018, the OECD Council invited Colombia to become a Member. At the time of publication the deposit of Colombia's instrument of accession to the OECD Convention was pending and therefore Colombia does not appear in the list of OECD Members and is not included in the OECD zone aggregates.

\section{(c) OECD (2019)}

You can copy, download or print OECD content for your own use, and you can include excerpts from OECD publications, databases and multimedia products in your own documents, presentations, blogs, websites and teaching materials, provided that suitable acknowledgment of OECD as source and copyright owner is given. All requests for commercial use and translation rights should be submitted to rights@oecd.org 


\section{ABSTRACT/RÉSUMÉ \\ Enhancing the social integration of Roma in Slovak Republic}

Roma account for almost one-tenth of the population in the Slovak Republic. They live mostly excluded from the general population in concentrated settlements, separated neighbourhoods or ghettos. The majority live in poverty and face social exclusion in almost all aspects of everyday life. Only a small share of Roma work, and a majority suffer from long spells of unemployment, their educational attainment is low, and a large number are illiterate. Social exclusion is further exacerbated by rising general animosity and mistrust between Roma and non-Roma groups. This calls for immediate policy action. The government should ensure easy access to all public services and provide additional support for the disadvantaged Roma communities. Individual policies should be effectively coordinated, because the problems that the Roma are facing are interconnected. A necessary precondition for successful Roma integration is the support of the general population. Policy interventions towards Roma integration should be accompanied by measures to eliminate the prejudices among parts of the majority population against their fellow citizens.

This Working Paper relates to the 2019 OECD Economic Survey of Slovak Republic (http://www.oecd.org/economy/surveys/slovak-republic-economic-snapshot/) JEL classification: I24, I26, I32, J15, J48

Keywords Roma, poverty, pre-school education, inclusion

\section{Mieux intégrer les Roms dans la société en République Slovaque}

Les Roms représentent près d'un dixième de la population de la Slovaquie. Ils vivent le plus souvent de manière isolée par rapport au reste de la population, dans des campements, des quartiers séparés, voire des ghettos. La majorité d'entre eux vivent dans la pauvreté et sont victimes de l'exclusion sociale au regard de la quasi-totalité des dimensions de la vie quotidienne. Seule une faible proportion de Roms travaillent : ils sont en grande majorité touchés par le chômage de longue durée, ont un faible niveau d'études et un grand nombre d'entre eux ne savent ni lire ni écrire. L'exclusion sociale des Roms est accentuée par un sentiment grandissant d'animosité et de méfiance entre les communautés roms et les autres. C'est la raison pour laquelle les pouvoirs publics doivent engager une action immédiate. L'État doit assurer aux communautés roms défavorisées un accès aisé à tous les services publics, et leur apporter une aide supplémentaire. Une coordination efficace des politiques est indispensable, dans la mesure où les problèmes auxquels sont confrontés les Roms sont étroitement liés les uns aux autres. L'intégration des Roms ne pourra réussir que si la population slovaque dans son ensemble y est favorable. Les mesures axées sur l'intégration des Roms doivent s'accompagner d'actions visant à lutter contre les préjugés à l'égard des populations minoritaires.

Ce Document de travail se rapporte à l'Étude économique de l'OCDE de la Slovaquie, 2019

Classification : I24, I26, I32, J15, J48

Mots clefs: Roms, pauvreté, éducation préscolaire, inclusion 


\section{Table of contents}

Enhancing the social integration of Roma in Slovak Republic .....................................................6 6

Roma in the Slovak Republic face extreme levels of social exclusion................................................ 6

Demographic trends underline the importance of Roma integration ............................................ 10

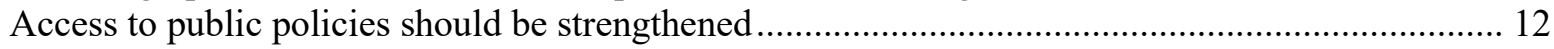

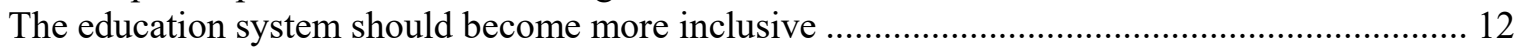

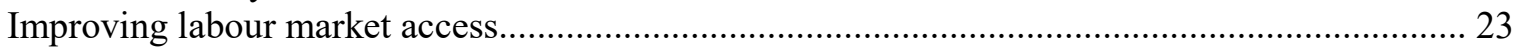

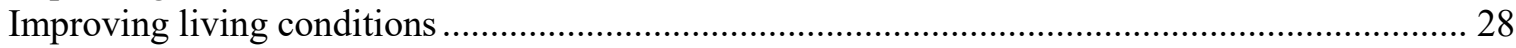

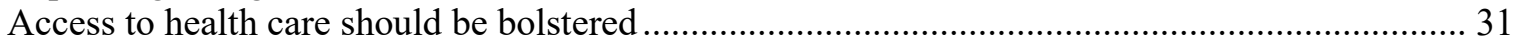

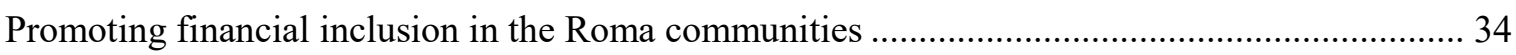

A holistic policy approach is needed to address Roma exclusion effectively ................................. 36

The current framework goes in the right direction, but could take a more systematic approach... 36

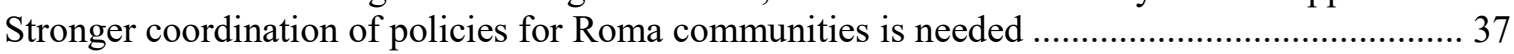

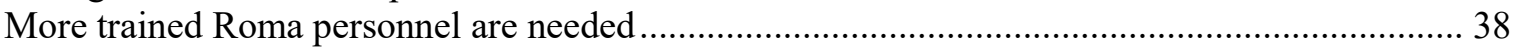

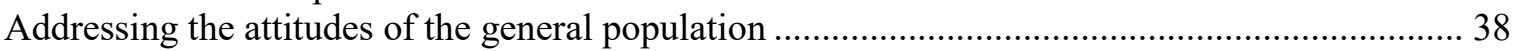

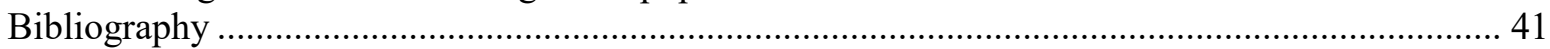

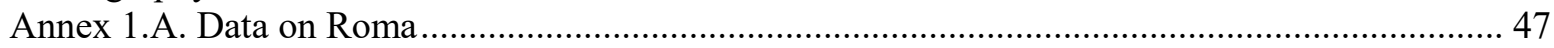

\section{Tables}

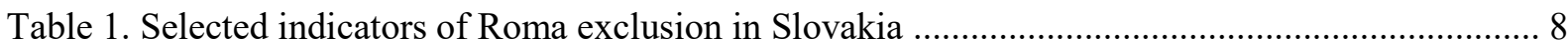

\section{Figures}

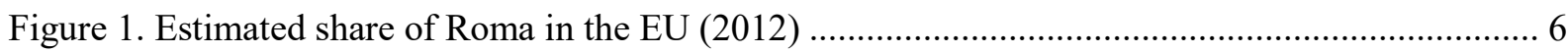

Figure 2. The vast majority of Roma are at risk of poverty ……..................................................... 7

Figure 3. Intergenerational mobility of Roma living in concentrated residential areas is low ............... 9

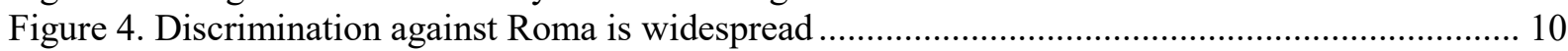

Figure 5. The Roma have a much younger population..................................................................... 11

Figure 6. Social inclusion of Roma will have positive effect on the economy .................................... 12

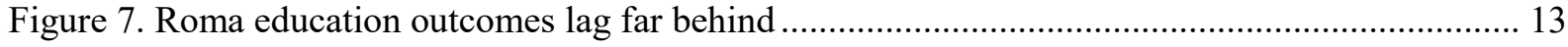

Figure 8. Pre-school attendance is low, especially for Roma (\%) .................................................... 14

Figure 9. Kindergartens are most often lacking in regions with higher Roma concentration ............... 14

Figure 10. Gap in PISA score ${ }^{1}$ compared to the rest of the population................................................ 17

Figure 11. Impact of socio-economic status ${ }^{1}$ on students' learning outcomes ..................................... 17

Figure 12. Disadvantaged students in Slovakia are more likely to repeat grades ................................ 19

Figure 13. Pupils who speak a different language at home from the language of assessment are

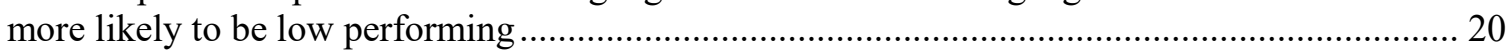

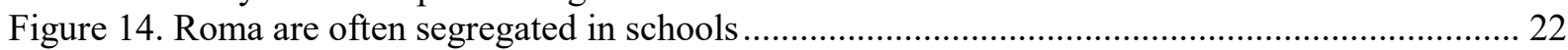

Figure 15. Slovakia has the highest share of pupils in the special schools ........................................... 23 


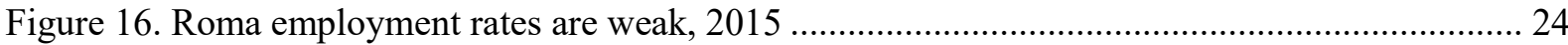

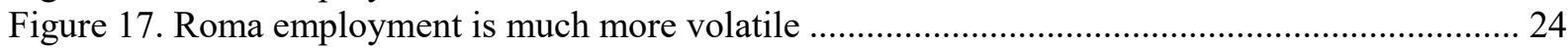

Figure 18. Spending on active labour market policies is low in Slovakia............................................ 25

Figure 19. Large share of unemployed Roma is in public work schemes .......................................... 26

Figure 20. Less educated job-seekers have higher probabilities of remaining unemployed for longer periods

Figure 21. Roma live in poor conditions with limited access to basic infrastructure ........................... 28

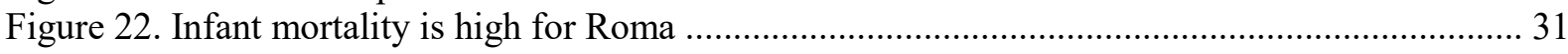

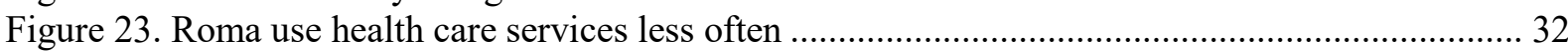

Figure 24. Financial constraints represent a barrier for Roma to seek medical services....................... 34

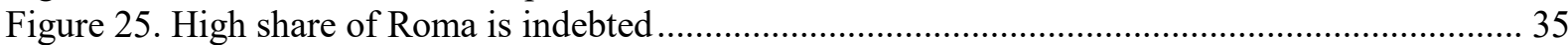

Figure 26. Awareness among Roma of laws prohibiting discrimination (\%) ..................................... 39

Figure A.1. Estimates of the size of the Roma populations differ........................................................ 47

\section{Boxes}

Box 1. Intergenerational mobility is very low for Roma.................................................................. 8

Box 2. School performance among disadvantaged groups in selected OECD countries ...................... 16

Box 3. Grade repetition is common among Roma students ............................................................... 19

Box 4. Successfully coordinated policy intervention at the local level............................................... 37 


\title{
Enhancing the social integration of Roma in Slovak Republic
}

\author{
By Michaela Bednarik, Slavomir Hidas and Gabriel Machlica ${ }^{1}$
}

\section{Roma in the Slovak Republic face extreme levels of social exclusion}

Today, with an estimated population of around 12 million, Roma people are one of the largest ethnic minorities in Europe. The Slovak Republic has one of the continent's largest Roma populations (Figure 1). Estimates differ, but it is assumed there are between 400000 and 500000 Roma in Slovakia, accounting for $7-9 \%$ of its population (see Annex 1).

Figure 1. Estimated share of Roma in the EU (2012)

$\%$

10

8

6

4

0

FRA

EU

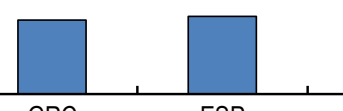

ESP

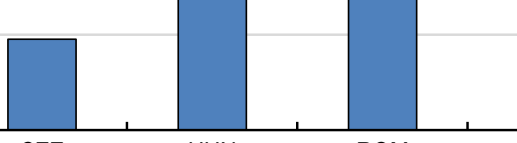

HUN

ROM

SVK

Note: Most data regarding the Roma is surrounded by uncertainty. The share represents the average of different estimates.

Source: Council of Europe, https://www.coe.int/en/web/portal/roma/

StatLink 젶ㄴ https://doi.org/10.1787/888933901978

${ }^{1}$ Gabriel Machlica is an Economist in the Country Studies Branch of the Economics Department of the OECD (gabriel.machlica@oecd.org). Michaela Bednarik was seconded from the Slovak Ministry of Education and Slavomír Hidaš was a secondee from the Institute for Financial Policy in Slovakia. The authors are grateful to numerous OECD Economics Department colleagues for their valuable comments, including Peter Jarrett, Claude Giorno, Paul O'Brien, Nicola Brandt, Patrick Lenain and Alvaro Pereira. The report also benefited from comments from the Slovak authorities. Special thanks are due to Klaus Pedersen for excellent statistical assistance and Elisabetta Pilati for editorial support. 
The migration of Roma to the Slovak Republic dates back to the $13^{\text {th }}$ century, when Roma were settling in suburbs and the edges of villages to develop their activities in crafts, trade and occasional seasonal work (Matlovicova et al., 2012). They were often subject to restrictive and exclusionary policies. Particularly before and during the Second World War, the Roma communities were often forcefully relocated and resettled, which has contributed to their spatial concentration. This formed the basis for the establishment of today's settlements, separated neighbourhoods or ghettos on the outskirts of villages and towns. The Roma communities vary based upon geographic location and the level of integration. Nevertheless, the average level of ethnic segregation is exceptionally high. Less than half of the Roma live dispersed among the general population and only onethird consider Slovak as their mother tongue (UNDP, 2014; UNDP, 2012).

The differences in living standards between Roma and the general Slovak population are striking. Per capita output of Slovak Roma is comparable to outcomes in sub-Saharan Africa (World Bank, 2012a). While the Slovak Republic has a comparatively low poverty rate, it is particularly pronounced among the Roma population. Findings from the EUMIDIS survey (2016) show the vast majority of Roma are at risk of poverty, and almost one-third living in households where at least one person went to bed hungry in the past month. Moreover, poverty is not only higher compared to the general population but is the highest among Roma in neighbouring countries (Figure 2).

Figure 2. The vast majority of Roma are at risk of poverty

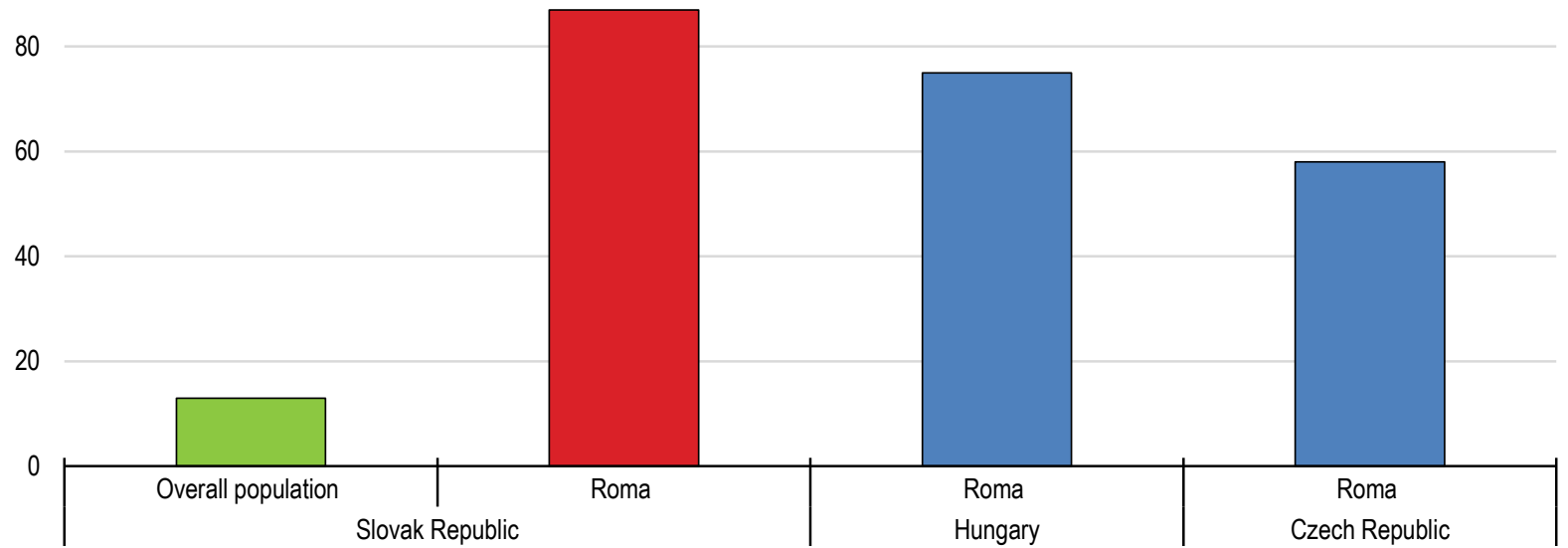

Note: At-risk-of-poverty based on the EU-MIDIS II survey are all persons with an equivalised current monthly disposable household income below $60 \%$ of the median equivalised national income. The equivalised disposable income is the total income of a household, after tax and other deductions, divided by the number of household members converted into equivalised adults.

Source: EU (2016), Second European Union Minorities and Discrimination Survey, Roma - Selected findings, European Union, Agency for Fundamental Rights.

StatLink त्ञाज https://doi.org/10.1787/888933901997

Roma face social exclusion in almost every aspect of everyday life (Table 1). Roma suffer from housing exclusion, depriving many households of heating, electricity and other essential domestic necessities. One-third of them are illiterate or state that they have difficulties reading (UNDP, 2012). Roma suffer from frequent spells of long-term unemployment, and only a small share have regular jobs. 
Table 1. Selected indicators of Roma exclusion in Slovakia

\begin{tabular}{lcc}
\hline & General population & Roma \\
\hline At-risk-of-poverty rate (\%) & 13 & 87 \\
Employment rate, 20-64, (\%) & 68 & 25 \\
NEET rate - neither in work nor in education, aged 16-24, (\%) & 14 & 65 \\
Drop-out rate from education, (\%) & 7 & 58 \\
Share of households living without a toilet, bathroom and shower inside the dwelling & 0.6 & 43 \\
Share of households living in areas affected by crime, violence and vandalism & 8.7 & 30 \\
\hline
\end{tabular}

Source: EU (2016), Second European Union Minorities and Discrimination Survey, Roma - Selected findings, European Union, Agency for Fundamental Rights.

However, social exclusion does not reflect preferences, as for example most Roma express a desire for stable jobs, and employed Roma have higher rates of self-reported happiness (World Bank, 2012a). At the same time, one survey confirms that Roma parents prefer their children to complete secondary or tertiary education (Gatti et al., 2016).

Widespread poverty and social exclusion have significant effects on life expectancy, and available evidence indicates that large health inequalities exist between the Roma and non-Roma populations. The estimated gap in life expectancy at birth is 6 years, depending on the degree of integration of the Roma communities (MoF, 2019). The situation is even worse in some districts where these marginalised groups have a life expectancy of barely 53 years, compared with 70 years for non-Roma people (OECD, 2017a; Soltès et al., 2014).

More worryingly, Roma can be trapped in a cycle of poverty for generations. If a child starts her or his life with limited access to education and lives in poor housing conditions, there is a high probability she will end up in poverty too. Indeed, results for Roma show exceptionally weak upward social mobility between generations. Younger generations of Roma have almost the same poor labour market outcomes as their parents; upward social mobility for Roma born in segregated and concentrated residential areas is extremely low. The probability that Roma born in concentrated residential area become unemployed or earn less than minimum wage in irregular work is almost $70 \%$ (see Box 1)

\section{Box 1. Intergenerational mobility is very low for Roma}

Lack of upward mobility at the bottom of the income distribution means that many potential talents are missed out or remain under-developed (OECD, 2018a). Intergenerational economic mobility is measured by the elasticity between paternal earnings and the adult earnings of their children. The work of the Financial Policy Institute (Rizman, 2018) confirms that intergenerational mobility is high in Slovakia, except for the poorest households. Here the same approach was followed to estimate the intergenerational mobility for Roma.

The intergenerational earnings elasticity is derived from a regression-to-the-mean model:

$$
\ln Y_{t i}=\alpha+\beta Y_{i, t-1}+\varepsilon_{t, i}
$$

Where Y represents "permanent earnings" for individuals from a family indexed by $i$, across two generations, $t$ and $t-1$. Following the example of Corak (2013), $Y$ refers to the earnings of fathers and sons, $\varepsilon$ represents all other influences on the 
child's adult earnings, the constant term $\alpha$ captures the trend in average incomes across generations and $\beta$ indicates the elasticity across generations within the same family in terms of the percentage difference in child earnings for each percentage point difference in parental earnings. Higher values of $\beta$ indicate a higher probability that the earnings of parents predict the adult income of a child. In contrast, lower $\beta$ values indicate that the relative earnings of parents are weak predictors of the earnings of a child.

The results show that the elasticity is much higher for Roma population whose elasticity is 39.5 , while the elasticity for the general population is only 18.4. Consequently, the earnings of parents are much better predictors of the earnings of children in the case of Roma, and a greater fraction of economic disadvantage can be passed from parents to their children.

Particularly, for Roma children coming from concentrated areas the probability to end up in poverty is high. The probability to become unemployed or earn less than the minimum wage in irregular work is almost $70 \%$, which is much higher compared to general population and even higher than the poorest non-Roma population (Figure $3)$.

Figure 3. Intergenerational mobility of Roma living in concentrated residential areas is low

Probability of being unemployed or earning less than a minimum wage according to parents' economic and ethnic status

Probability

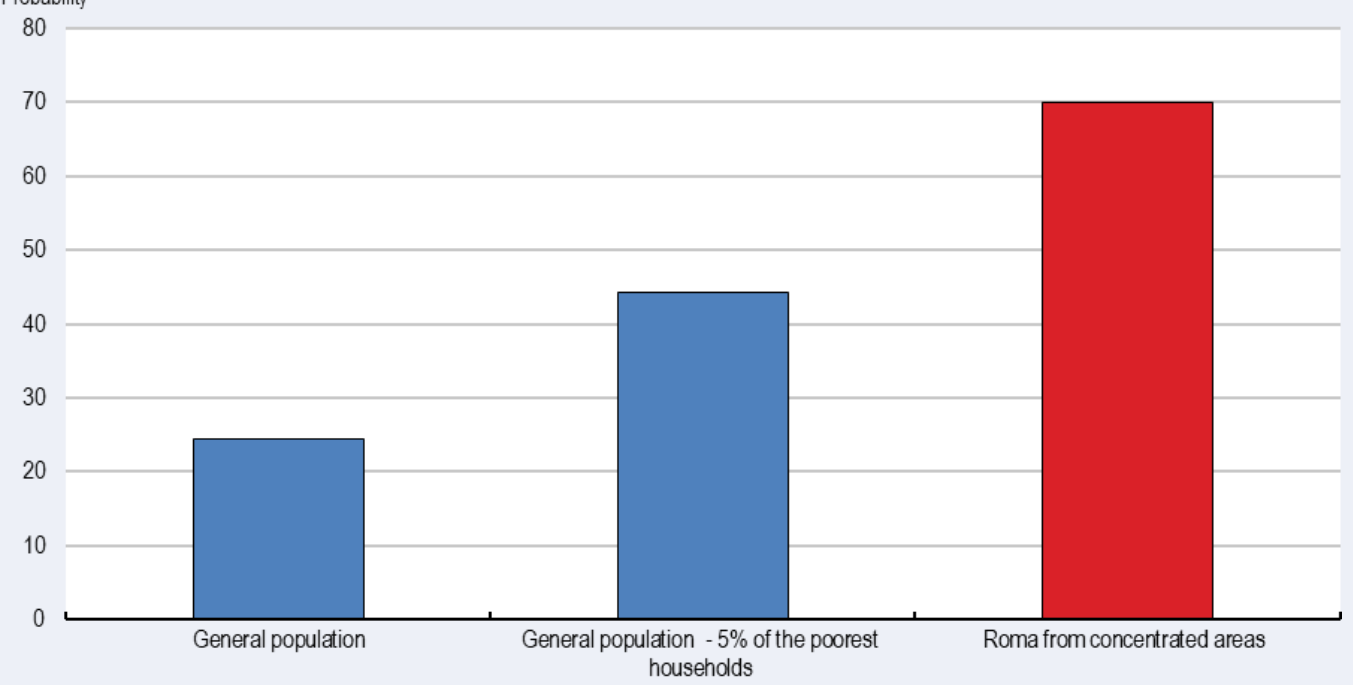

Source: OECD calculation based on J. Rizman (2018), "Jablko padá d'aleko od stromu", Institute for Financial Policy, Ministry of Finance of the Slovak Republic, Policy Brief, No. 09.

StatLink तinst https://doi.org/10.1787/888933902016

Social exclusion is further exacerbated by general animosity and mistrust between Roma and non-Roma groups. Findings from EU-MIDIS survey (2016) show that more than half of the Roma population felt discriminated against because of their Roma background at least once in the past five years, particularly during job search (Figure 4). 
Figure 4. Discrimination against Roma is widespread

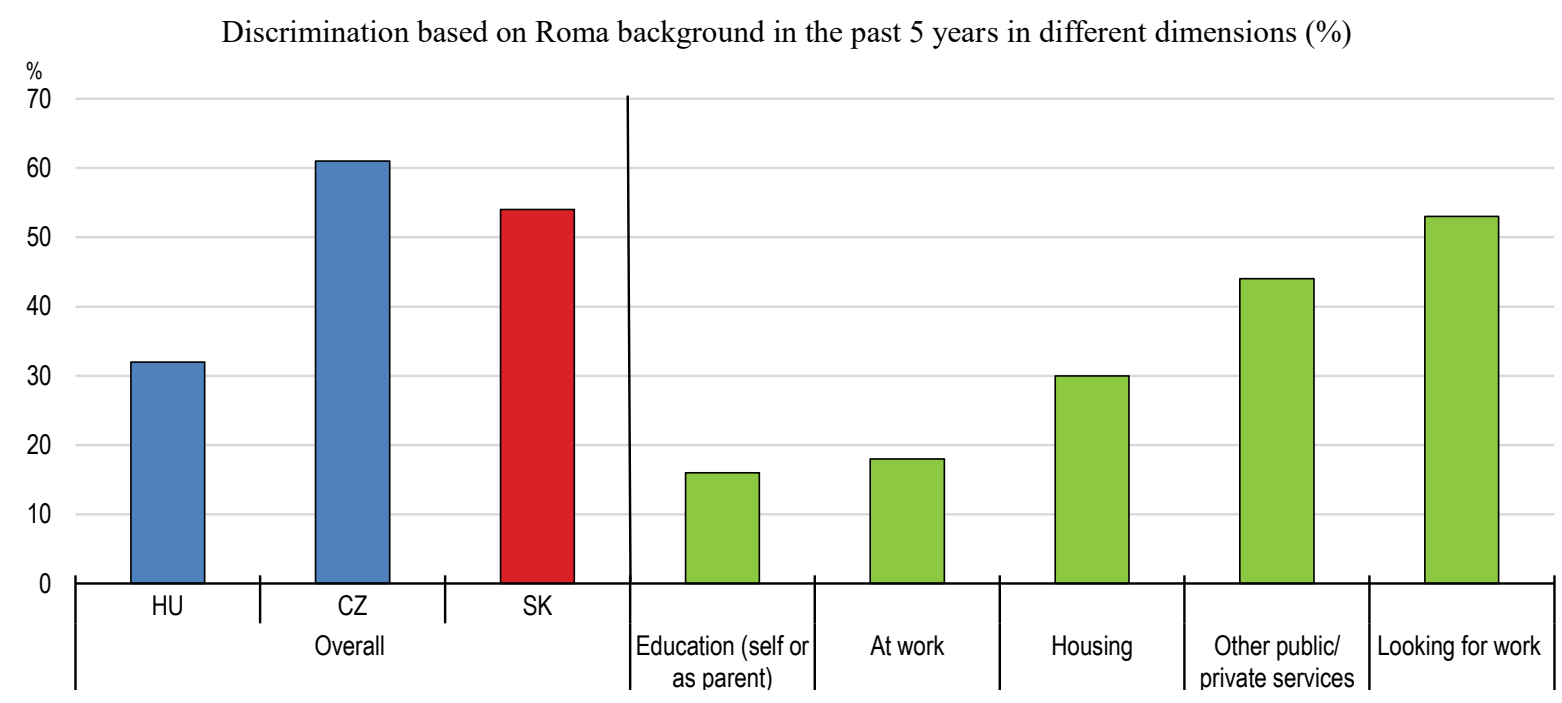

Note: Out of all Roma respondents at risk of discrimination on grounds of Roma background in the past 5 years in at least one of the domains of daily life asked about in the survey.

Source: EU (2016), Second European Union Minorities and Discrimination Survey, Roma - Selected findings, European Union, Agency for Fundamental Rights.

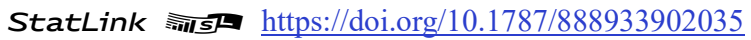

This was confirmed by an experiment performed by the Financial Policy Institute, which sent a batch of fictitious job applications to employers; only one-third of those with Roma names got a response, while $70 \%$ of the applications with non-Roma names received a response (Machlica et al., 2014). Comparable examples can be found in schools, where parents from the majority population tend to prefer schools without Roma children. More than half of the general population in Slovakia stated that they would feel uncomfortable if their children had Roma schoolmates (Eurobarometer, 2012). In some extreme cases physical walls and barriers have been erected to segregate Roma from the rest of society (ERRC, 2013).

At the same time, the Roma population lack trust in local governments and public institutions. This is also partly related to their under-representation in party politics and public administration. The three officially registered Roma parties are politically insignificant. The 2012 parliamentary elections brought in the first Romani Member of Parliament since the country gained independence. There are increasing numbers of Roma mayors and members of local parliaments, but Roma are still severely underrepresented in communal, provincial and national elective bodies.

\section{Demographic trends underline the importance of Roma integration}

Over the longer term demographic trends with a higher fertility rate among Roma imply that the Roma share of the population will increase. There is a large disparity in the demographic structure of the Roma vs non-Roma populations (Figure 5). Overall, the Slovak Republic has one of the fastest ageing populations in the OECD. The Slovak population, which is currently one of the youngest in the European Union is projected to become the $6^{\text {th }}$ oldest by 2070 (EC, 2017a). In contrast, the Roma population is expected to increase. The median age of the Roma population is 24 years in comparison with 37.5 years for the non-Roma (Sprocha, 2014). The share of the Roma population is expected to increase from $8 \%$ to $14 \%$ by 2060 (OECD, 2017a). 
The high level of social exclusion and increasing share of Roma population call for immediate policy actions. The government should prioritise integrating the Roma in order to build a more inclusive society, which ensures that nobody is left behind. Reaching this goal requires vision and long-term commitment.

Figure 5. The Roma have a much younger population
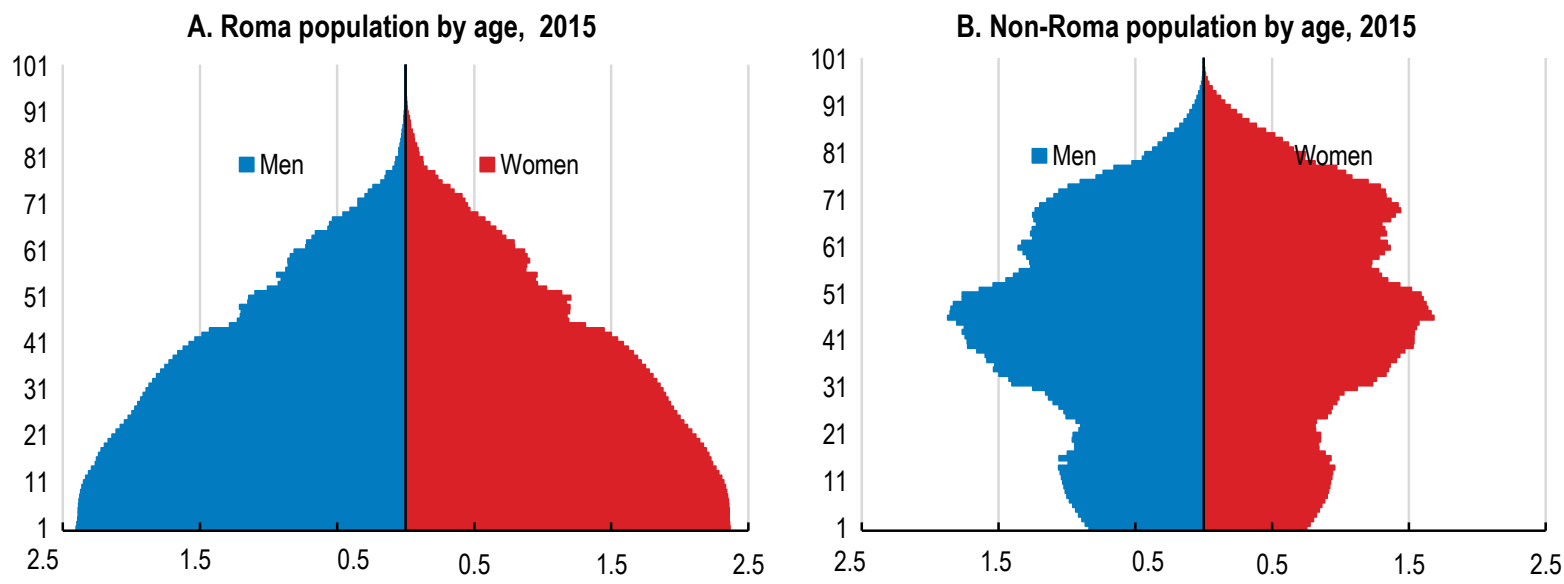

Source: B. Sprocha (2014), Reprodukcia rómskeho obyvatel'stva na Slovensku a prognóza jeho populačného vývoja, INFOSTAT - Výskumné demografické centrum.

StatLink त्गाजम https://doi.org/10.1787/888933902054

\section{Roma integration is an investment for the whole society}

Successful Roma integration would also increase the supply of qualified labour, which can boost the economy, help alleviate labour shortages and also can help to mitigate the effects of rapid ageing (Figure 6, Panel A). Successful Roma integration requires additional funding (see below). However, investment in Roma integration cannot only help improve the well-being of disadvantaged groups, but also yield positive fiscal returns from improved employment prospects. For example, empirical estimates suggest that opening professions, such as medicine and law, to women and black people who did not previously pursue them due to occupational and human capital barriers, was an important source of growth for the US economy (Hsieh et al., 2018). The cost of excluding the Roma minority is significant (Marcincin and Marcincinova, 2009), 
Figure 6. Social inclusion of Roma will have positive effect on the economy
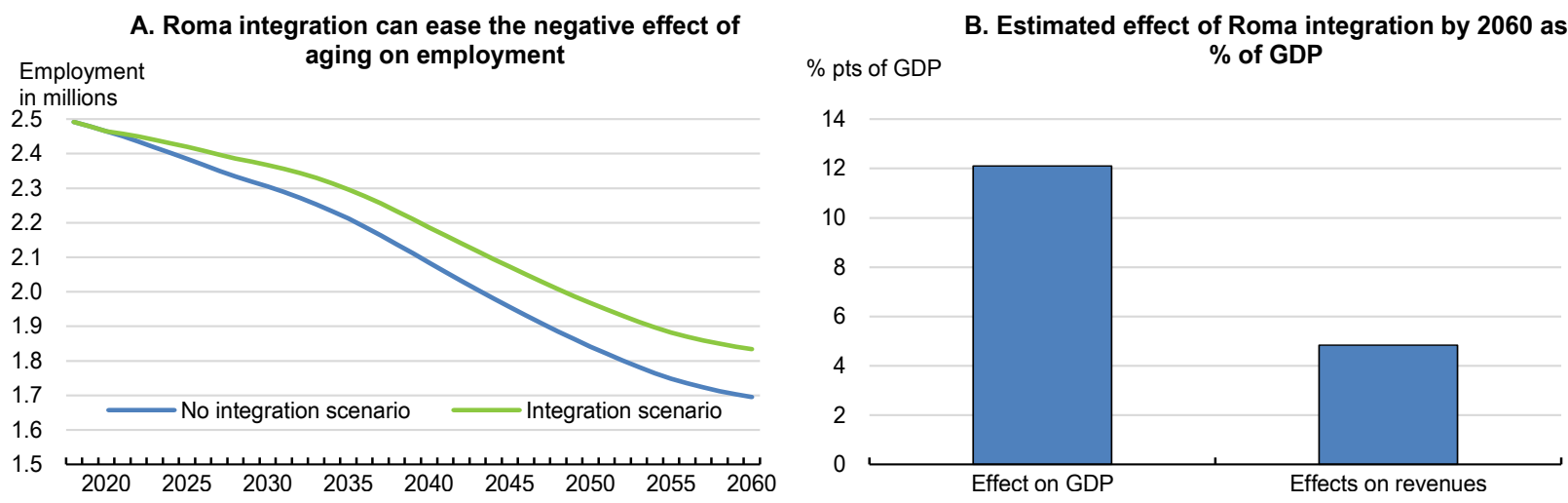

Note: The estimated impact is calculated as a difference between two scenarios. (i) "No integration scenario" assumes no convergence of Roma in terms of relative productivity and the employment rate, which remain at the current level (ii) "Integration scenario" assumes convergence of the employment rate and productivity of Roma to the level of the general population by 2060. Both scenarios assume a rising share of Roma population. See more details in the Technical Background Paper.

Source: Geva, A., S. Hidas and G. Machlica (2019), "The benefits of social inclusion of Roma in the Slovak Republic", Technical background paper, forthcoming.

StatLink त्गा5 https://doi.org/10.1787/888933902073

Increasing the Roma employment rate and their productivity to the level of the general population by the end of 2060 would increase GDP by more than $12 \%$ (Figure 6 ) with the economy growing faster on average by 0.3 p.p. per year. At the same time, a higher employment rate and wages of the Roma will bring additional fiscal revenues, worth around an estimated 5\% of GDP by 2060 .

\section{Access to public policies should be strengthened}

Ensuring access to public services and providing additional support is necessary to level the playing field for the disadvantaged Roma communities. This will require coordinated interventions in different policy areas including: (i) education, (ii) labour market policies, (iii) health care, (iv) housing and (v) financial inclusion.

\section{The education system should become more inclusive}

Education can be a powerful instrument for improving equity and reducing poverty. However, the Roma have low educational attainment: more than half of them drop out of school, and only a few manage to reach tertiary education Figure 7, Panels A and B). The outcomes of Roma students are significantly worse than those of their non-Roma counterparts. The performance difference in PISA scores between Roma and non-Roma pupils at the age of 15 years is about 160 points, which corresponds to almost five years of schooling (Panel C). 

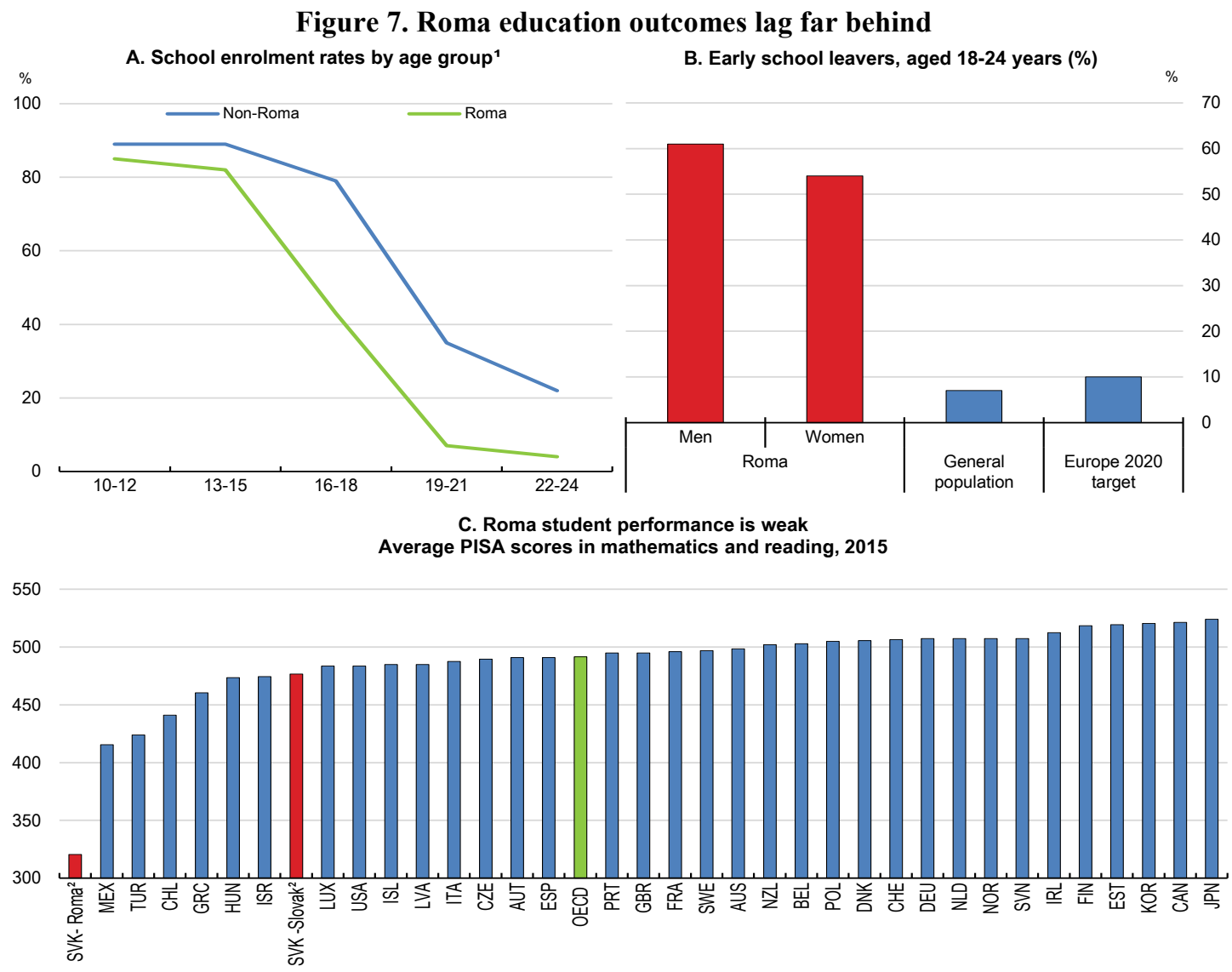

1. Share of Roma and non-Roma living in close proximity to Roma households who attend school by age group.

2. Each group is based on the same language spoken at home.

Source: OECD (2016), PISA 2015 Results (Volume I): Excellence and Equity in Education; OECD calculations based on PISA 2015 Database; EU (2016), Second European Union Minorities and Discrimination Survey, Roma - Selected findings, European Union, Agency for Fundamental Rights.

StatLink तiाs https://doi.org/10.1787/888933902092

\section{Expanding participation in pre-school education}

Participation in high-quality early childhood education and care (ECEC) can help significantly improve child development. Indeed, PISA analysis confirms that Slovak youth with pre-primary education are at much lower risk of becoming low performing students (OECD, 2016). Empirical estimates suggest that the benefits of pre-school education go beyond positive effects on children's learning and extend to their health and wellbeing (OECD, 2018b). In the Slovak Republic pre-school education is optional and in contrast to most countries in the EU, places in ECEC are not legally guaranteed in Slovakia (EC/EACEA/Eurydice, 2016). Only one-third of Roma attend kindergarten compared with almost $80 \%$ in the overall population and $90 \%$ in most OECD countries (Figure 8). It is important to stress that the duration of participation also matters: empirical research suggest that students who attended early childhood education for less than a year are 3.1 times more likely to perform below the baseline level of proficiency in science than students who attended for one or more than a year (OECD, 2018b). 
Figure 8. Pre-school attendance is low, especially for Roma (\%)
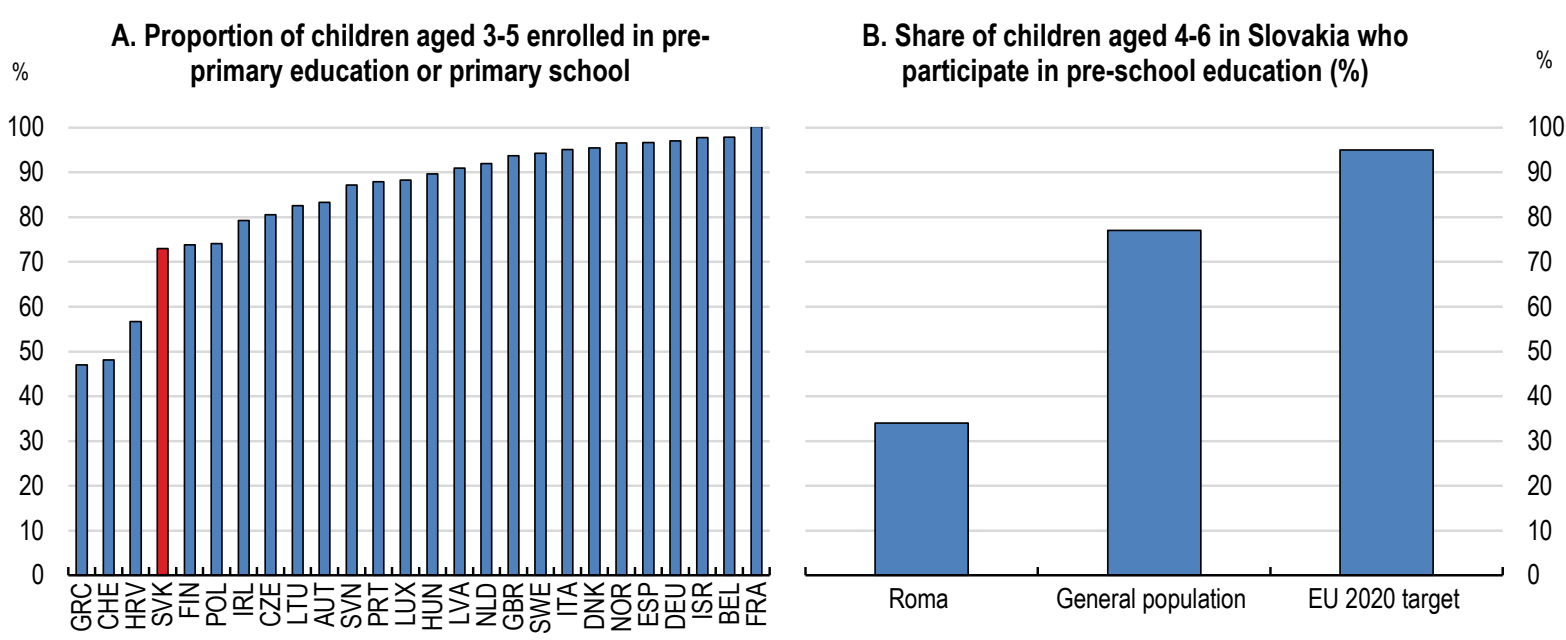

Source: OECD Family database; EU (2016), Second European Union Minorities and Discrimination Survey, Roma - Selected findings, European Union, Agency for Fundamental Rights.

\section{StatLink त्राज https://doi.org/10.1787/888933901693}

Pre-school capacities are insufficient despite the ongoing EU-financed expansion (MoF, 2019). Municipalities without a kindergarten tend to be in regions with higher concentrations of Roma population (Figure 9). Due to the high demand, kindergartens prefer children of working parents and families with permanent residences, conditions which often effectively disqualify Roma parents (To da Rozum, 2018).

Figure 9. Kindergartens are most often lacking in regions with higher Roma concentration

50

45

40

35

30

25

20

15

10

5

$\mathrm{BR}$ $\square$ Share of municipalities with Roma communties

Source: UNDP (2014), Atlas Romskych komunit na Slovensku 2013, Regionálne centrum Rozvojového programu OSN Pre Európu a Spoločenstvo nezávislých štátov v Bratislave.

\section{StatLink 제느 https://doi.org/10.1787/888933902111}

At the same time, the low participation of the Roma can be attributed to cultural and financial barriers or discrimination. Roma parents often refuse to send their children to kindergarten, as they feel they are too young to be enrolled (UNDP, 2012). Also, some 
Roma parents do not have access to information on the process of enrolment and are not aware of the formal requirements. Transport costs also present a significant barrier for many Roma families, as some remote Roma settlements have only limited public transport options (RECI, 2018). In addition, there are cases of discrimination against Roma. These include petitions against the opening of kindergartens with a prevalence of Roma children (RECI, 2018).

Moreover, tuition and other fees can represent a significant barrier for Roma. Pre-school education is run by municipalities and there are no limits regarding tuition fees. Therefore, the fees can vary significantly between municipalities, from 7 euros per month up to 300 euros per month (MoF, 2019). The out-of-pocket childcare costs relative to income for children age 2-3 years are among the highest in the OECD (OECD, 2017b). These costs include enrolment and other fees such as for transport or extracurricular activities.

In order to boost the participation of Roma in pre-school education it will be necessary to increase the number of pre-school facilities with more investments on top of EU funds. Nurseries and kindergarten should be prioritised in public spending. In general, investments in early childhood education are considered to have high returns. Empirical research confirms that the rate of return on investment in human capital is the highest at an early age. Early interventions is found to be more cost efficient than remedial education interventions later in life (OECD, 2011; Schweinhart, 2006; Heckman et al., 2009). In the short run, these steps can be complemented by expanding licensed homebased pre-school education for younger children to meet these demands with relatively limited investment (OECD, 2018b).

Participation in pre-school education should be compulsory for 5 year-olds, and legal entitlements should be introduced for 3-4 year-olds. Several other EU member countries, such as Bulgaria, France, the Czech Republic, and Hungary have already introduced obligatory pre-school education. This in Hungary resulted in the same enrolment rate in kindergartens for Roma and non-Roma children.

Nevertheless, the reform should be carefully implemented to ensure high quality across all pre-school facilities, because low-quality pre-school education can have even detrimental effects on development and learning (OECD, 2018c). Therefore, greater funding should be provided to adequately staff the teaching positions as well as supporting personnel with adequate training. In this regard the authorities should consider transferring the pre-school funding from municipalities to the Ministry of Education and financing ECEC through appropriate normative (Santiago et al., 2016). As an intermediate step, the funding should be targeted at disadvantaged populations such as Roma.

The demand for pre-school education among disadvantaged groups should be bolstered. The government should cover the hidden costs of education such as transport. A conditional cash transfer programme was introduced in Hungary in 2009 for disadvantaged children aged 3 to 4 and led to much higher enrolment (Kertesi and Kézdi, 2013). The government recently decided that as of January 2019 lunch will be free of charge for every pupil in the last year of kindergarten and in elementary school. In addition, the Slovak government in 2018 introduced a child-raising allowance to partially cover the costs for pre-primary education for children one year before starting primary education. These are steps in the right direction, but the support should be expanded further to identify and cover the hidden costs for all disadvantaged children. 
In addition, local municipalities and social workers should raise awareness of the benefits of early education. Parental involvement and the presence of Roma personnel can alleviate the distrust among Roma parents towards ECEC. Creating parent support groups or opportunities for Roma parents' participation in school activities can help integrate children into the ECEC environment. These parent outreach programmes should be drawing on experience of national pilot projects and international projects (EC, 2017b). For example, as a programme in New Zealand - "Engaging Priority Families" - provides support to children and their families, helping them attend ECE regularly, supporting learning at home and assisting them with the transition to school(OECD, 2015a).

\section{Box 2. School performance among disadvantaged groups in selected OECD countries}

Improving the performance of students with different social and cultural background remains a significant challenge for many OECD countries. The school outcomes measured by PISA tests suggest that the gaps between these disadvantaged groups and the rest of the population are significant (Figure 10). The gap of Pisa scores of Roma in Slovakia with the rest of the Slovak population, amounts to almost 5 years of schooling, is substantially higher than that of Arab-Israelis compared with the rest of Israeli population (about $3 \frac{1}{2}$ years) and the Maori and the Pasifika people compared with the rest of the New Zealand population (between $1 \frac{1 / 4}{4}$ and $13 / 4$ years).

Māori represent $15 \%$ and Pasifika people almost $8 \%$ of the New Zealand population. On average, they have lower incomes and poorer social and health outcomes than non-Māori. Māori and Pasifika achievement remains below that of the rest of the population. A cornerstone of the New Zealand governments' strategy for accelerating the progress of Māori and Pasifika students is to ensure that all pre-school children have access to highquality early childhood education. Progress has been made in reducing nonparticipation rates for Pasifika and Māori children, from 24\% and 17\%, respectively, in 2000 to $9 \%$ and $6 \%$ in 2016 (OECD, 2017c).

Israeli-Arabs represent one fifth of the population in Israel. They have a different school system and live mostly in separate cities. This contributes to different outcomes in the labour market, education and earnings (OECD, 2018d). Although disparities in school outcomes remain significant, there has been an improvement in the achievements of IsraeliArab students. The level of formal education attained by teachers in the Arab system has improved and enrolment rates in pre-primary and post-primary education, which lagged behind the Hebrew sector rates, are now almost identical (Blass, 2017). 
Figure 10. Gap in PISA score ${ }^{1}$ compared to the rest of the population

Expressed in equivalents of years of schooling

6

5

4

3

2

1

0

Roma - Slovakia ${ }^{2}$

Israli - Arabs

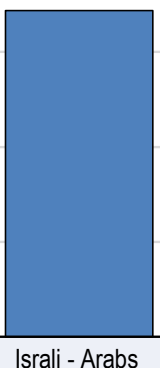

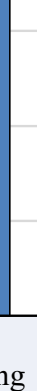

1. Average PISA score in mathematics and reading
2. Roma are identified by the language spoken at home.

Source: OECD, PISA Results, S. May, J. Flockton and S. Kirkham (2016), PISA 2015 - New Zealand Summary

Report, Ministry of Education.

StatLink 젶ㄴ https://doi.org/10.1787/888933902130

\section{Providing support to low performers and disadvantaged schools}

Due to severe poverty in the settlements, many Roma face several difficulties upon entering the primary-school environment, and their school readiness is hindered by limited participation in pre-school education. At the same time the Slovak school system is not properly equipped to overcome these barriers. Indeed, the impact of socioeconomic background on student outcomes in Slovakia is one of the highest in the OECD (Figure 11).

Figure 11. Impact of socio-economic status ${ }^{1}$ on students' learning outcomes

10

5

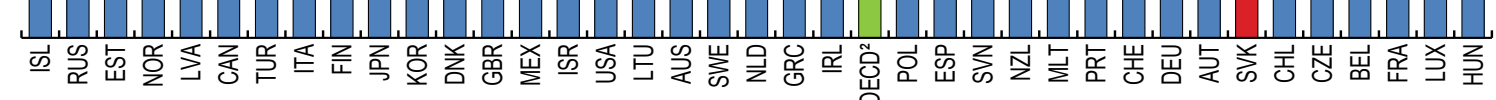

1. A student's socio-economic status is estimated by the PISA index of social, cultural and economic status, which is based on such indicators as parental education and occupation, the number and type of home possessions that are considered proxies for wealth and the educational resources available at home.

2. Unweighted average.

Source: OECD, PISA 2015 Database, Table I.6.3a.

StatLink 제내 https://doi.org/10.1787/888933902149 
There are two main financial instruments used to limit the impact of socio-economic background on students' performance. The first is the SDE (socially disadvantaged environment) allowance paid to schools based on the number of disadvantaged students. The school can use this allowance for several purposes, for example for teaching assistants. In 2017 the amount of the allowance per student was EUR 260, and a half was spent on teaching assistants/social pedagogues or teachers' allowances (MŠVVŠ, 2017). The second instrument is a separate allowance paid to schools for lunches or materials for disadvantaged students.

However, the support from the SDE allowance is insufficient. It represents together only $0.84 \%$ of the current budget for primary education. Weak funding results in an insufficient number of teaching assistants or social pedagogues. There are about 260 teaching assistants and 78 social pedagogues in Slovakia, translating to one per 120 disadvantaged students. In many other OECD countries the financing of schools with weaker socio-economic profiles is much more generous. For example, in Chile a weighted voucher system was adopted that provides 50\% more resources for students from poor socio-economic backgrounds (Elacqua, 2012). Therefore, funding for schools with the high share of disadvantaged students needs to increase and should be subject to regular monitoring and evaluation.

At the same time these financial instruments are not well targeted in Slovakia. Pupils' disadvantaged status is determined either by the Pedagogical Centres, which have limited capacities, or is based on household income. In the case of household income, the disadvantaged pupils are those from households receiving the "assistance in material need" (AMN), which is a social assistance to those whose income falls below the subsistence minimum. However, this does not cover all the poor households in Slovakia properly. For example, some families receiving parental leave benefits lose eligibility for AMN. As a consequence, these instruments cover only $35 \%$ of the overall number of pupils coming from households at risk of poverty (MoF, 2019). Thus, many schools host these disadvantaged pupils without additional funding.

Therefore, the conditions to receiving higher funding for disadvantaged pupils should be broadened to better reflect schools' needs. For example, the educational attainment of parents is used in the Netherlands and language needs of pupils in several OECD countries to determine if a school needs more funding (OECD, 2012; EASI, 2016; OECD, 2017d).

\section{Attracting the best teachers to disadvantaged schools}

The main support should be targeted at teachers. Teacher quality can have the largest effect on the performance of students, strong enough to close the achievement gaps between advantaged and disadvantaged students (Chetty et al., 2014; Schacter and Thum, 2004).

Teachers in the Slovak Republic are poorly paid and have lower general skills than people in other professions (OECD, 2017a). Moreover, experienced teachers are in short supply in schools in socioeconomically disadvantaged regions (Santiago et al., 2016). Among schools attended by 15 year-olds, the likelihood of teacher shortages is considerably higher in schools both with plenty of socio-economically disadvantaged students and in those located in rural areas.

The incentives for the best teachers to work in the schools with the most disadvantaged students are weak in Slovakia. The maximum salary supplement for teaching disadvantaged pupils is EUR 25 per month, representing less than $2 \%$ of the average teacher wage. However, some other countries use much more generous financial 
incentives to attract the best teachers to teach in disadvantaged schools. For example, Brazil increased the salaries of teachers by $60 \%$ in real terms for those working in poorer areas $(\mathrm{OECD}, 2014 \mathrm{a})$. Increasing the salaries of teachers in disadvantaged schools should not come at the expense of other teachers, as the salaries of teachers are already among the lowest in the OECD (OECD, 2017a). Experience from other countries suggests that these financial incentives should be complemented by other incentives (OECD, 2012). For example, Korea offers in addition to a salary premium multiple incentives to candidates working in high-needs schools, such as smaller class sizes and additional credits towards future promotion.

These incentives should be further accompanied by teacher training, which will help improve the quality of teaching in disadvantaged areas. Teachers in Slovakia rarely employ a differentiated and individualised approach that respects the diverse educational needs and abilities of their pupils (SSI, 2016). Teachers report that the offered professional training courses do not correspond to their needs, and special-needs and student-behaviour courses are the most demanded (TALIS, 2013). Teachers should be prepared to teach students from diverse backgrounds, and this training should be included in the training strategies for teachers. In addition, tertiary education should design programmes that include mandatory courses covering multiple aspects of diversity (EC, 2017c; OECD, 2015b). For example, in Finland, all teachers are trained in adapting their teaching to the varying learning needs and styles of their students (OECD, 2012).

More differential and individualised teaching approaches can help address grade repetition (Box 1.3) and drop-out rates, which are more pronounced among the Roma community. This should be further supported by activities outside the formal curriculum. Evidence shows that the availability of additional time in school for disadvantaged students through extra academic and social activities can have positive effects on academic performance and motivation (OECD, 2012). Different learning-time options can include after-school and holiday learning programmes.

\section{Box 3. Grade repetition is common among Roma students}

Grade repetition is internationally low in the Slovak Republic (PISA, 2015). However, in the Slovak education system disadvantaged pupils are more likely to repeat a grade, and this relative likelihood is the highest among the OECD countries (Figure 12).

Figure 12. Disadvantaged students in Slovakia are more likely to repeat grades

Likelihood of disadvantaged students to repeat a grade, relative to advantaged students

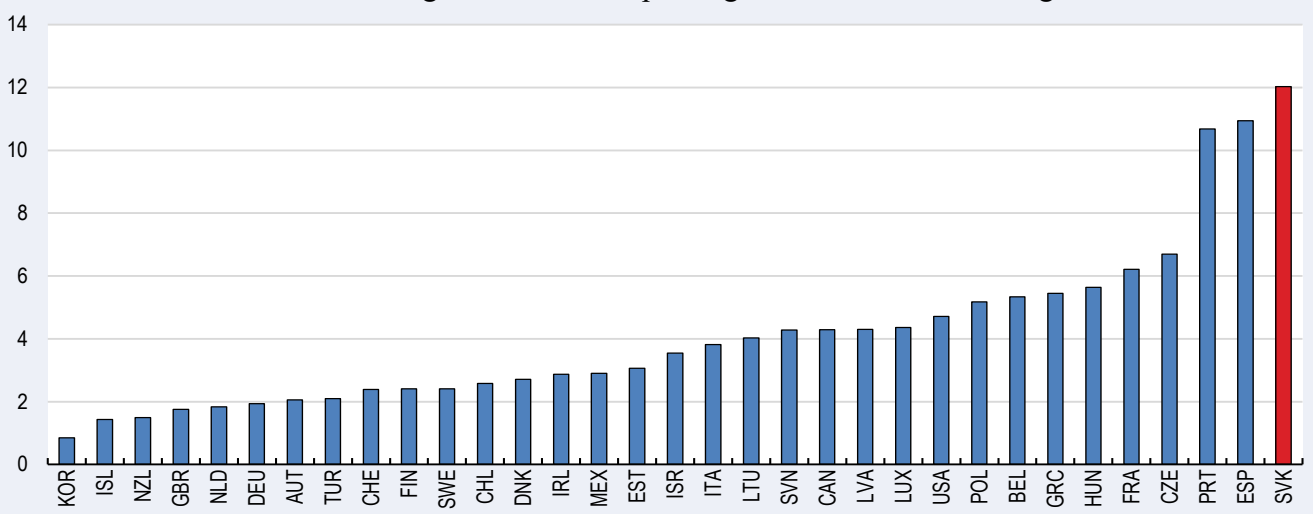

Source: OECD, PISA 2015 Database, Table I.6.14

StatLink त्राज् https://doi.org/10.1787/888933902168 
Grade repetition can significantly affect pupils' chances of reaching secondary education. Repeated years are counted to the 10-years of compulsory education, while the primary education is nine years. Therefore, those who repeat grades several times can reach 10 years of compulsory education without completing primary school. Even zero grades, aimed at achieving school readiness, can be repeated (SZ, 2018; CVTI, 2017).

Grade repetition does not effectively address underperformance in school; moreover, it is likely to undermine pupils' confidence and trigger early school leaving (OECD, 2007).

\section{Addressing language barriers}

Only one-third of Roma consider Slovak as their mother tongue (UNDP, 2012). Many Roma do not speak Slovak or are bi-/trilingual, speaking a combination of Romani, Slovak and Hungarian. This represents an important barrier for integration, as proficiency in the language of instruction is a fundamental determinant of successful educational outcomes. Students who do not master the language of instruction are at a significant disadvantage in schools (Nusche, 2009).

However, the Slovak education system fails to help pupils to overcome these language barriers. Indeed, students speaking a different language at home from that used in school are more likely to be perform poorly. This probability is higher in the Slovak Republic than in other OECD countries, even after controlling for students' other socioeconomic characteristics (Figure 13). Very few schools provide Romani as a support language or Romani-language textbooks (Gallová-Kriglerová et al., 2012). Most teachers and support staff do not speak Romani, and Roma teachers are significantly underrepresented: there are only 10 primary and lower secondary teachers that declared a Roma origin (CVTI, 2014; SSI, 2016). Schools do not provide any language support for those to whom Slovak is not a mother tongue.

Figure 13. Pupils who speak a different language at home from the language of assessment are more likely to be low performing

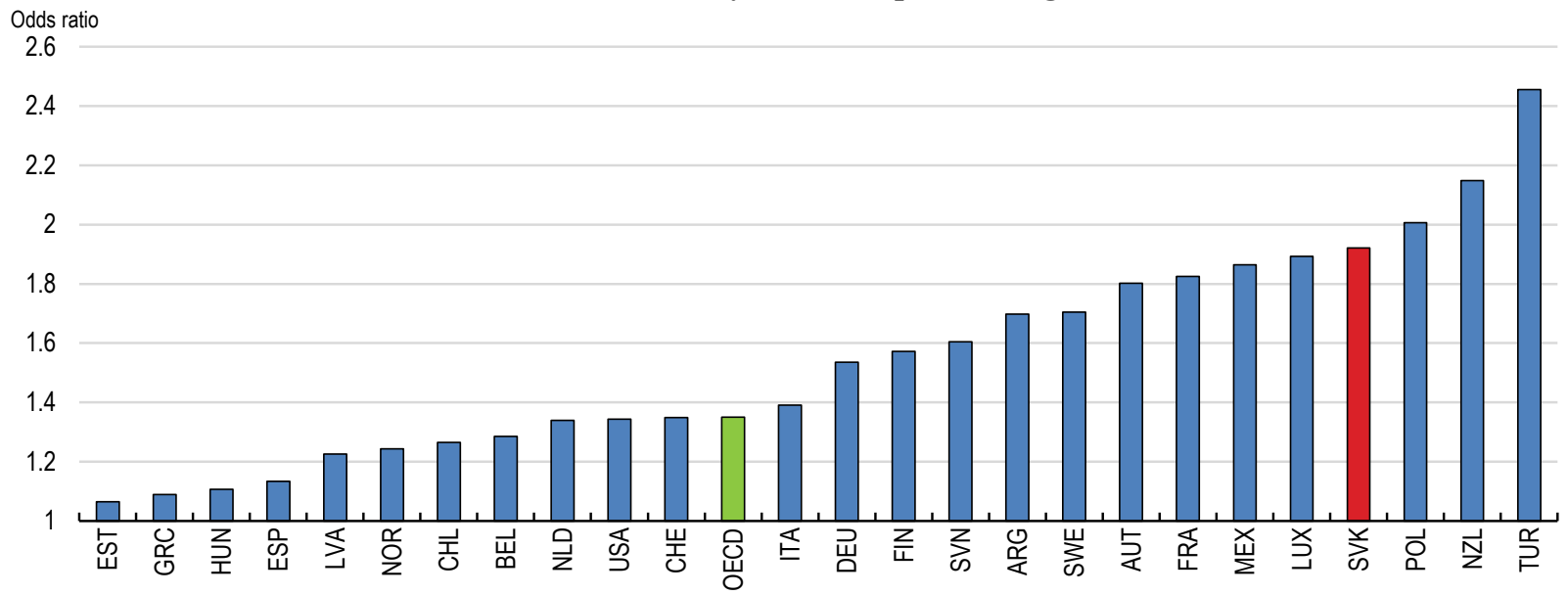

Note: The estimates control for other characteristics including: socio-economic status, family structure, immigrant background, location of student's school (rural or urban area), attendance at pre-primary school, grade repetition and programme orientation (vocational or general).

Source: OECD (2016), Low performing students, OECD Publishing, Paris.

StatLink ज्ञाs https://doi.org/10.1787/888933902187 
Considering the language diversity of its student population, Slovakia should introduce a systematic language policy. Options and strategies for learning Roma should be covered in both initial and in-service training for teachers (OECD, 2015b). The government should introduce programmes to increase the number of Roma teachers and teaching assistants in schools. Examples of successful projects show that Roma teaching assistants improve the educational achievements of Roma children and help change attitudes of Roma parents towards higher school attainment (EC, 2016; Gatti et al., 2016). However, it is important to ensure that implementation of these steps will not lead to segregation (EC, 2018).

At the same time additional Slovak language support for Roma students should be introduced. Teachers should be able to identify those needing extra language training. These additional language support can start in pre-primary school. For example, in Israel the government is expanding Hebrew lessons, including in kindergartens, and $120 \mathrm{Arab}$ kindergartens are getting acquainted with Hebrew for two hours a week (OECD, 2018d).

\section{Tackling segregation}

In the Slovak Republic segregation in education is prohibited, but still there is evidence of activities that can lead to Roma concentration in schools (Amnesty International, 2017). Children in Slovakia usually attend a school in the school district where they reside unless their parents decide otherwise. School districts are established at the municipal level. There is evidence that some municipalities have started to establish school districts according to the areas resided by Roma in order to avoid the enrolment of Roma in predominantly non-Roma schools. At the same time the phenomenon of white flight is also present, when non-Roma students leave the schools with a prevalence of Roma students.

The school segregation of Roma has been confirmed by a landmark court ruling in the case of Sarisske Michalany and widely documented by the Slovak state school inspection and several NGOs. Since 2015 Slovakia also faces an ongoing infringement proceeding by the European Commission for discrimination against Roma in education. The majority of Roma children report that they attend schools and classes in which all or most of their schoolmates are Roma (Figure 14). Segregated exclusive Roma schools exist mostly in predominantly Roma areas. However, there is evidence of exclusive Roma classes in mainstream schools, segregated buildings and even segregated dining facilities for Roma (SSI, 2016). International evidence confirms that ethnic and socio-economic composition of schools and classes is one of the most important variables explaining pupils' systematic low achievement and educational attainment (OECD, 2009). This is particularly important for Roma, as strong socio-economic selection bias is strengthening the perception of poor quality and creating a vicious circle in the expectations of teachers and students.

Therefore, schools should be helped and incentivised to desegregate and school choice should be coupled with student-allocation schemes which would ensure that children are distributed to schools in a more diverse manner. For example, places might be reserved or ratios set for students of certain ethnic origin, socially disadvantaged or disabled students. 
Figure 14. Roma are often segregated in schools

Proportion of Roma who state that all or most of the schoolmates are Roma, share in \%

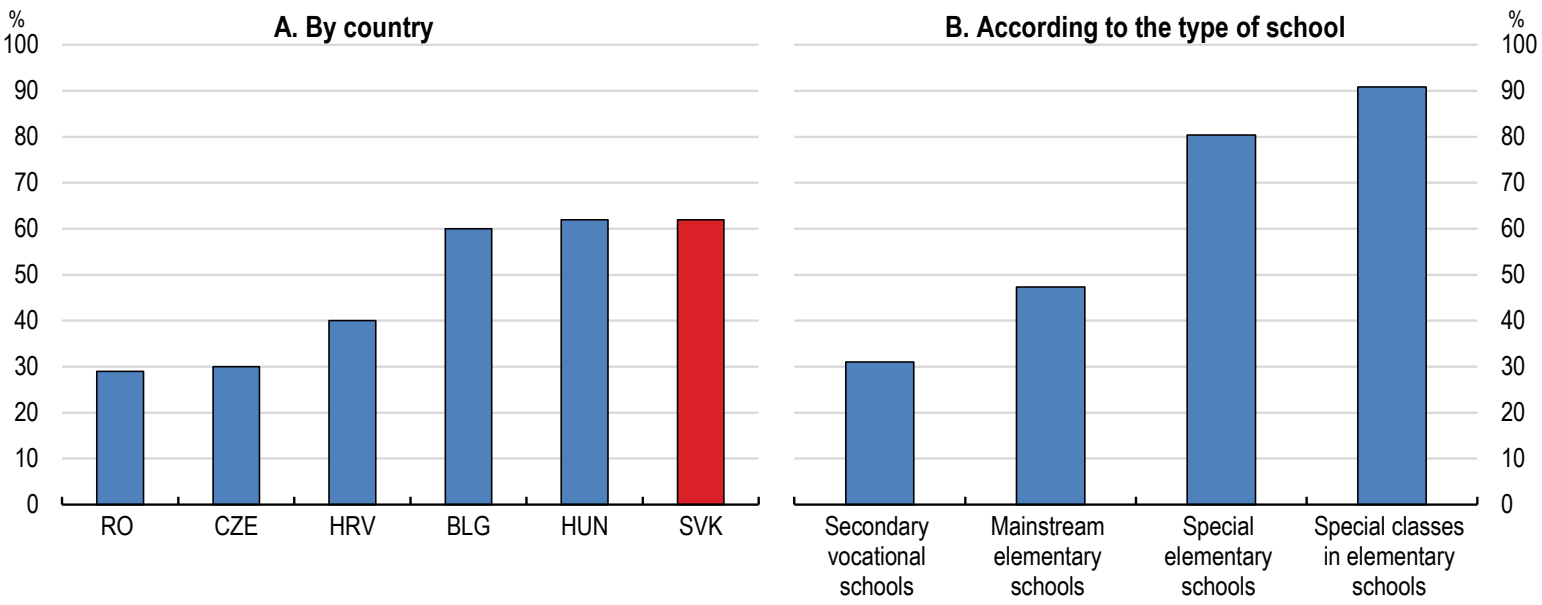

Source: European Union Agency for Fundamental Rights (2016), UNDP (2012a), Report on the Living Conditions of Roma Households in Slovakia 2010, www.undp.org/content/dam/ rbec/docs/Report-on-theliving-conditions-of-Roma-households-in-Slovakia-2010.pdf.

StatLink ज्ञात https://doi.org/10.1787/888933902206

Another approach would be to redefine school districts coupled with a policy of school transportation (busing) (CoE, 2017; OECD, 2012). The schools should be prepared for desegregation with better teacher training (see above), and support staff such as assistants, special pedagogues, psychologists and others should form an integral part of the school inclusiveness.

More worryingly, Roma are overrepresented in special schools (Figure 15) that are supposed to provide education for children with disabilities. An initiative was launched in 2015 to prevent misdiagnosis of Roma students. Still, the Roma represent more than half of all pupils in special classes and more than $40 \%$ in special schools, while their share in mainstream education is only $10 \%(\mathrm{MoF}, 2019)$. Overall, Slovakia has the highest population share educated in special settings (Figure 15). Completion of special basic schools (ISCED 2) does not allow their graduates to pursue their education at the regular secondary schools (ISCED 3), which significantly limits their further education and labour market prospects. Thus, enrolment in special schools has negative long-term effects in terms of future educational and labour market outcomes.

The high share of Roma in special schools is partly a consequence of misdiagnosis. There are still tendencies to treat children with learning difficulties as mentally disabled, medicalising the socio-economic disadvantages (Santiago et Al., 2016). Field research has confirmed that the testing results are in some cases arbitrary and subjective (CVEK, 2018; Amnesty, 2017; World Bank, 2012a; SSI, 2016). Also, many special schools are trying to attract new students as their survival depends on the per capita funding based on the number of enrolled students. In addition, some Roma parents prefer special schools for their children as they are more easily accessible, and offer a less demanding curriculum that can be handled at a slower pace and a more familiar environment (CVEK, 2018; SGI, 2013; UNDP, 2012). Roma parents are often not aware of negative effects of special schools on educational and labour market prospects. 
Figure 15. Slovakia has the highest share of pupils in the special schools

Note: How many pupils with an official decision of SEN are educated in separate special classes in mainstream schools or in separate special schools in ISCED 1 + ISCED 2:

Source: European Agency for Special Needs and Inclusive Education

StatLink तins https://doi.org/10.1787/888933902225

There is evidence that these children can do well in regular classes if provided adequate support. A pilot research project that followed Roma families who emigrated to the United Kingdom showed that children who had previously been placed in special schools were able to successfully complete primary and secondary education at integrated, mainstream schools (Equality, 2011; World Bank, 2012a).

Rather than using assessment instruments to stream children into special education, diagnostics should be used to identify individual needs and these needs should be addressed within a regular primary school with correspondingly increased funding for the school. In line with the current international practice (Latvia, Malta, Norway) some special schools could be transformed into resource centres for mainstream schools. In this way teachers could benefit from the valuable expertise of special school staff (EC, 2016; SGI, 2013). Regular re-diagnosis should become compulsory. Lastly, social workers and Roma mediators should work closely with families and provide relevant information about schools and their impact.

\section{Improving labour market access}

The Roma employment rate lags significantly behind that of the general population. Only one-quarter of the adult Roma population have a paid job, and this ratio is considerably smaller than for the non-Roma population, but also lower than for the Roma population in neighbouring countries (Figure 16). Moreover, there is a substantial gender gap. Men's average employment rate is twice that of women, which is explained by traditional gender roles, as Roma women are engaged in domestic work and childcare (Gatti et al., 2016). The unemployment rate of Roma is more than $40 \%$, with most of the Roma population being unemployed for more than a year (MoF, 2018). 
$\%$

Figure 16. Roma employment rates are weak, 2015

80

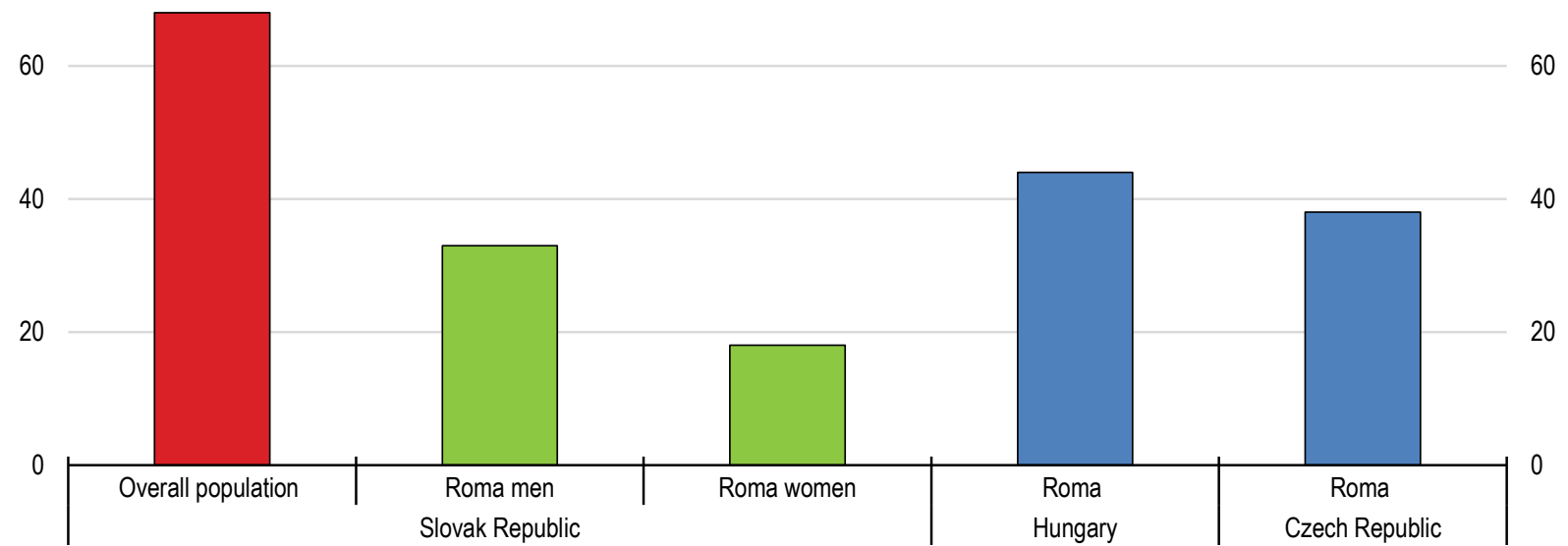

Source: EU (2016), Second European Union Minorities and Discrimination Survey, Roma - Selected findings, European Union, Agency for Fundamental Rights.

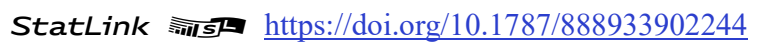

Roma who are employed face high job uncertainty and instability. Roma work mostly in construction (World Bank, 2012a) or in low skilled jobs. Their overall employment is characterised by high volatility, suggesting a prevalence of short term/seasonal contracts (Figure 17). This indicates lower job quality than for the general population. Also, the average wage of employed Roma is $40 \%$ lower than for the non-Roma (Geva, Hidas and Machlica, 2019). In addition, many Roma work in the informal economy, which increases their costs of job insecurity, as they are not entitled to unemployment benefits when they are out of work (Gatti et al., 2016). All these factors place Roma at a higher risk of falling into poverty when faced with a health or employment shock.

Figure 17. Roma employment is much more volatile

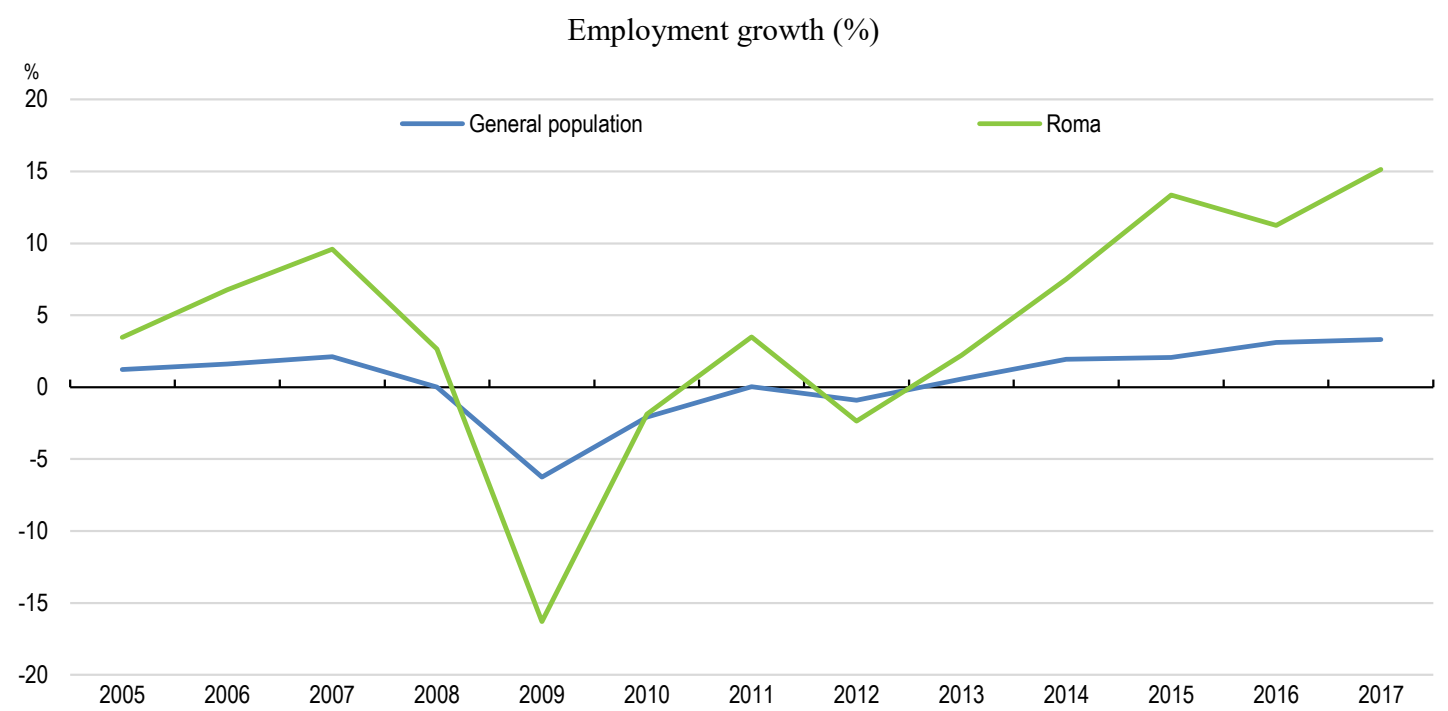

Source: Geva, A., S. Hidas and G. Machlica (2019), "The benefits of social inclusion of Roma in the Slovak Republic", Technical background paper, forthcoming

StatLink 제내 https://doi.org/10.1787/888933902263 


\section{Roma often participate in public works schemes}

The Slovak Republic has one of the highest shares of long-term unemployed in the OECD, partly due to weak labour market outcomes of Roma. Empirical research confirms that long periods of unemployment have been shown to have 'scarring' effects, and the long-term unemployed are more difficult to bring back to the labour market (OECD, 2013). Therefore, long-term unemployment requires more complex labour market policy interventions and correspondingly higher funding. However, Slovak spending on active labour market policies remains low, particularly in the context of high long-term unemployment (Figure 18).

Figure 18. Spending on active labour market policies is low in Slovakia

$$
\text { As a percentage of GDP per capita, } 2015 \text { or latest available }{ }^{1}
$$

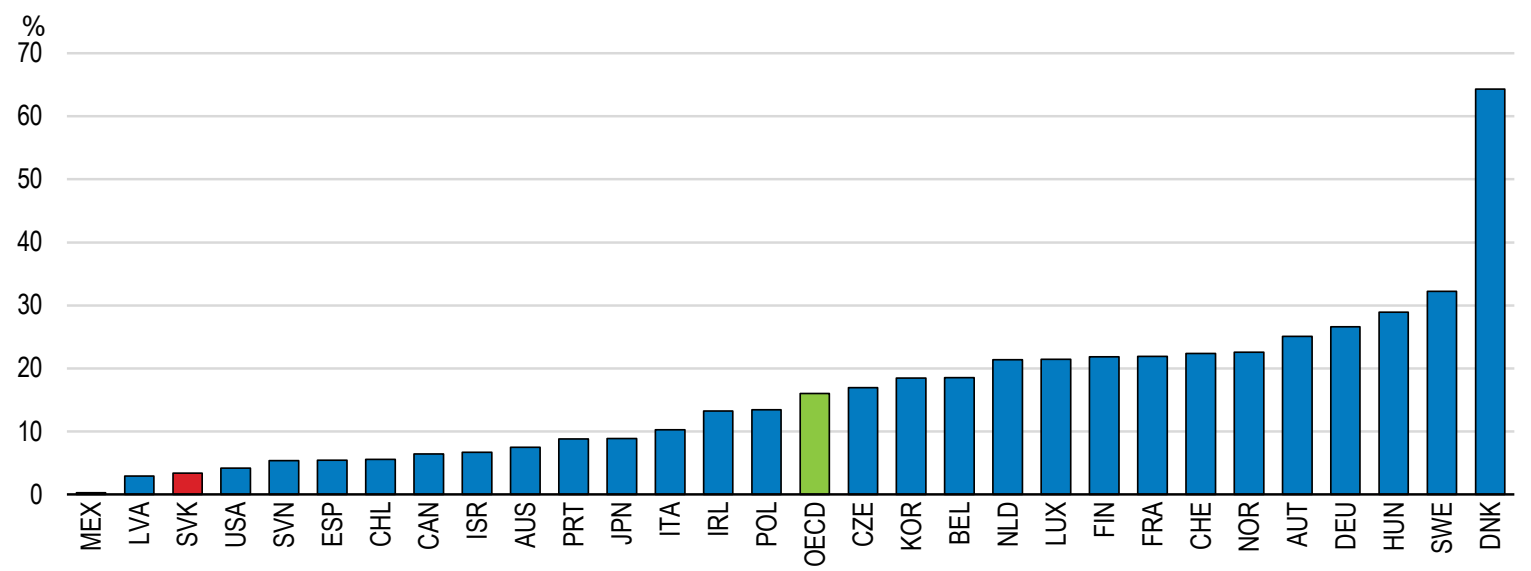

Note: The OECD aggregate is calculated as an unweighted average of the data shown. Source: OECD Employment and Labour Market Statistics (database).

StatLink त्ताI

The major programme that reaches marginalised Roma who are unemployed are the public works schemes. Almost half of Roma participating in active labour market policies are in these schemes (Figure 19). They typically offer jobs in the public sector to help the unemployed maintain basic skills, such as work routine and time management and last between 6 and 18 months. Participants receive a lump-sum benefit that is often the only means of supplementing income from the AMN in less developed regions in Slovakia (Kureková et al., 2013). 
Figure 19. Large share of unemployed Roma is in public work schemes

Share of participants in different ALMP programmes (\%)

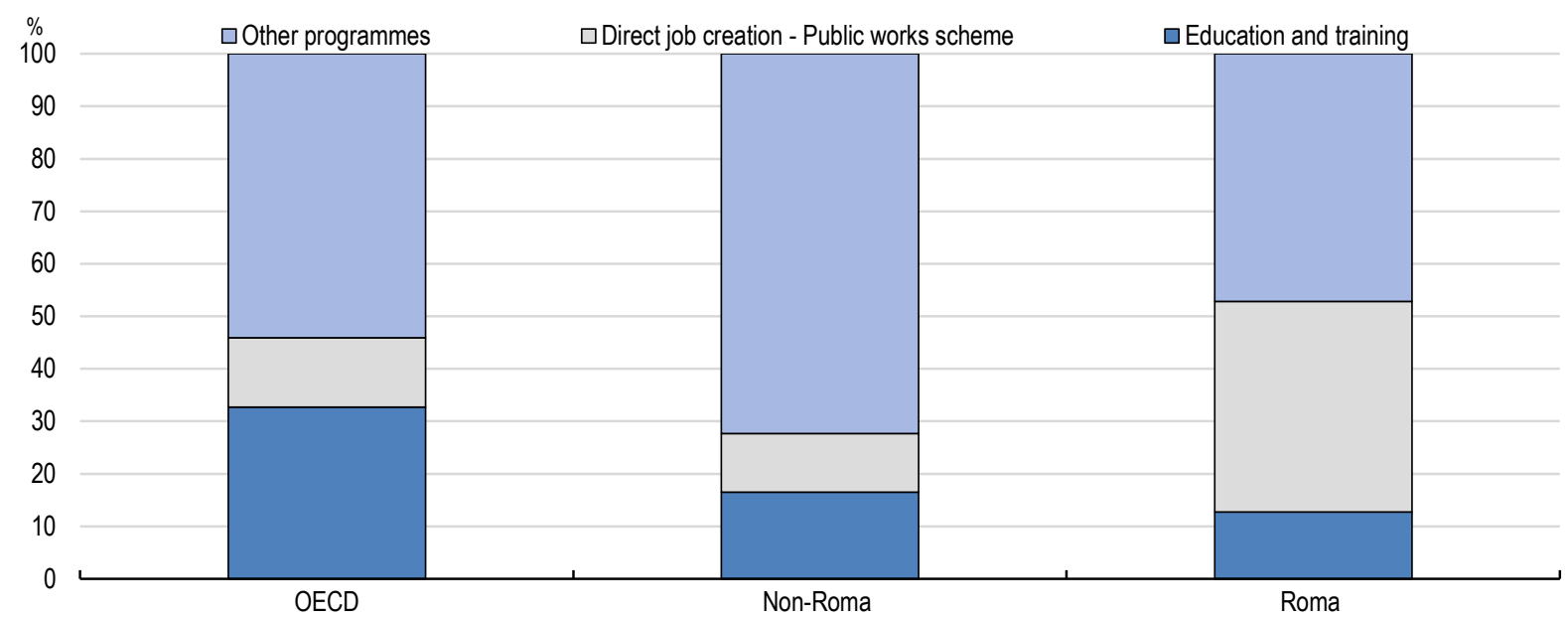

Source: Geva, A., S. Hidas and G. Machlica (2019), "The benefits of social inclusion of Roma in the Slovak Republic", Technical background paper, forthcoming

StatLink तilst https://doi.org/10.1787/888933902301

However, these programmes do not provide the relevant skills, and only a small share of participants subsequently finds a job in the labour market (Hidas et al., 2016). Repeated participation can then cause lock-in effects that prevent enrolees from job search or training activities. This confirms other countries' experience that shows that participation in such schemes can lower the probability of finding employment after the programmes have ended, leading to a long-term exclusion from the primary labour market (Card et al., 2015; Duell et al., 2010; World Bank, 2012b).

At the same time, Roma are underrepresented in other measures of active labour market policies, which have much higher potential for labour market integration. More than $40 \%$ of the active Roma population is unemployed, but they are three times less likely to be engaged in employment-incentive schemes or training programmes than the general population (Geva, Hidas and Machlica, 2019). In particular, training measures can significantly improve participants' skills and employability (Card et al., 2015; EC, 2015). Only one tenth of Roma in the ALMPs have participated in training programmes, compared to $30 \%$ on average in the OECD.

\section{Support for the long-term unemployed should be strengthened}

The large share of long-term unemployed and of ethnic minority job seekers among the unemployed calls for higher ALMP spending. The overall spending on activation policies should increase, and (i) the training measures should be strengthened and (ii) ALMP support should target hard-to-place job-seekers, particularly Roma, who represent its largest share.

Increasing training provision is necessary, as a lack of skills represents a significant barrier for Roma to access the labour market. As was mentioned previously, many Roma enter the labour market with a low educational level, which increases their risk of becoming long-term unemployed (Figure 20). Therefore, second-chance education should 
be strengthened by designing and developing a network of relevant providers. Also, training courses, linked to local employers' needs, should be offered. These courses can include training courses for jobs such us health mediators, kindergarten teachers and teaching assistants, which will help to employ Roma, but will also help other aspects of Roma integration.

These measures can be complemented by on-the-job training. Employers can play a key role in providing opportunities and training for participants. Empirical research confirms that employment-incentive schemes in the private sector can improve the employability of low-skilled participants (Card et al., 2015). Subsidies can be offered to private employers offering on-the-job training for hard-to-place job-seekers. For example, a successful public-private partnership programme called BladeRunners in Canada provides on-the-job training through cost sharing for courses, buying equipment and wage subsidies (OECD, 2012).

Establishing closer links with employers can also help bridge the information gap between the Roma community and employers. Trained social or community workers can help provide information about prospective Roma employees. The successful example of the US Steel Kosice factory shows that bridging this information gap leads to a substantial increase in Roma employment. In this case a local church in Kosice working in the Roma community helped the US Steel factory to identify prospective and eager-towork Roma employees who were subsequently hired (Gatti et al., 2016).

Figure 20. Less educated job-seekers have higher probabilities of remaining unemployed for longer periods

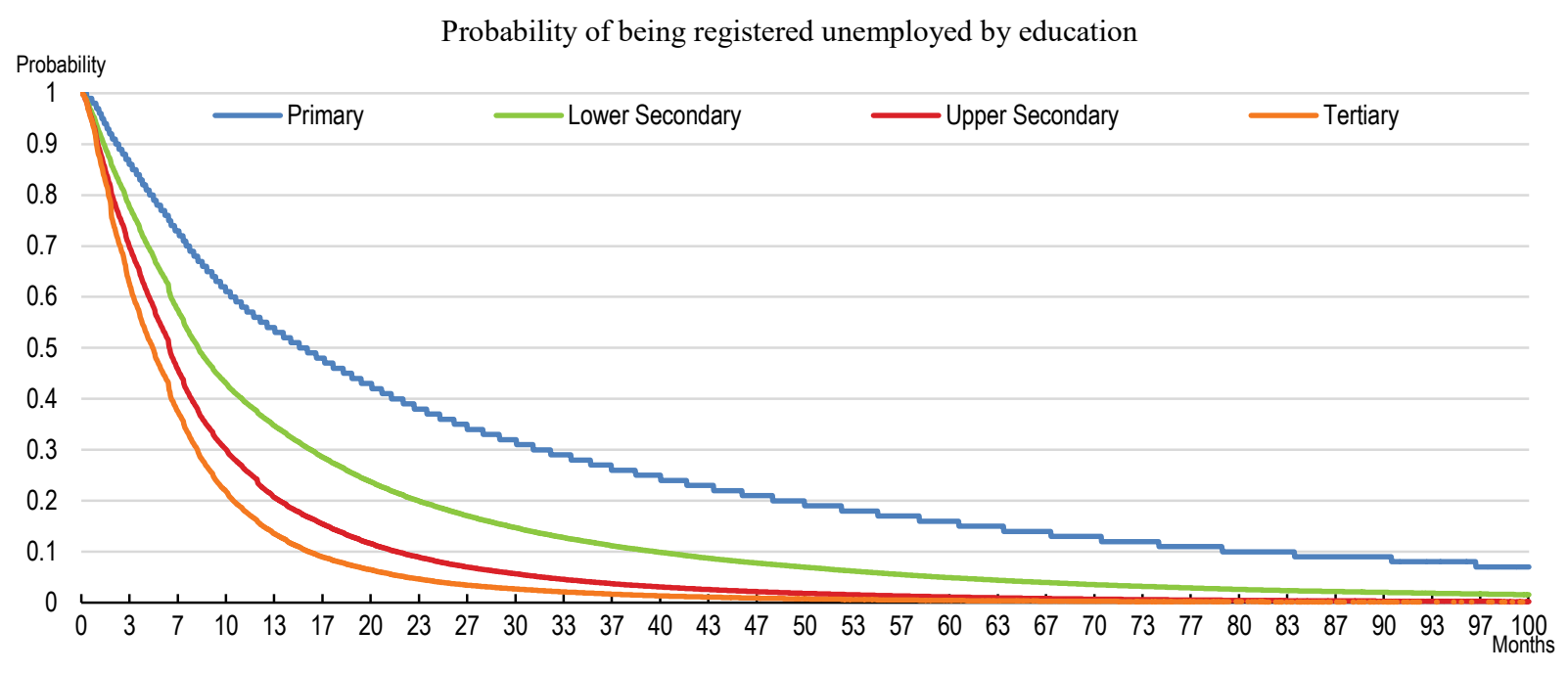

Source: MoF (2016), "Vel'a práce na úradoch práce: Efektivita a účinnost' služieb zamestnanosti" Institut Financnej Politiky, Ministerstvo Financii Solovenskej Republiky, http://www.finance.gov.sk/Default.aspx?CatID $=11228$

StatLink तilst https://doi.org/10.1787/888933902320

ALMP measures, including training, should be better linked with the needs of the unemployed by introducing a comprehensive profiling of the unemployed. Many longterm unemployed Roma require tailored individual action plans that offer a mix of training, counselling and mentoring programmes. The action plans should address the multiple social needs of the clients, including Roma-specific constraints such as poor health, housing and transport issues, indebtedness or limited availability of childcare. The 
intervention should be implemented in close cooperation with other public services (see below).

Despite some improvements in public employment service (PES) staffing, labour offices remain understaffed, which allows them to do only necessary administrative work. They do not have the capacity to implement client-oriented individualised services (Kurekova and Duel, 2013), which many jobseekers need, particularly the Roma. To provide individualised support, the public employment services need to be better staffed. Collaborating with private services, including NGOs, with a good track record of high quality support for Roma can help ease capacity constraints. In some cases, the labour offices could consider to outsource the services to non-state providers to improve the outcomes of job-seekers from disadvantaged groups (Tergeist and Grubb, 2006). Providers can be motivated by a payment system that rewards entries into the labour market that last for a predefined period of time, for example 6 months. Systematic performance monitoring and impact evaluation of ALMP programmes and monitoring of outsourced services should be implemented to determine if measures are well targeted, efficient and as effective as intended (World Bank, 2012a).

\section{Improving living conditions}

Living conditions and housing are dire in concentrated Roma settlements. Many Roma do not have sufficient income to build or buy adequate housing, so many of them live in provisional dwellings built from mud, soil, wood or other construction scrap. Almost half live in derelict houses or slums (Figure 21, Panel A). Furthermore, dwellings are overcrowded, with an average six people per housing unit and often in very bad conditions with leaking roofs and rot in the walls (FRA, 2016). With the expected increase in the Roma population, this problem could worsen.

Figure 21. Roma live in poor conditions with limited access to basic infrastructure

Selected indicators of Roma versus non-Roma living conditions
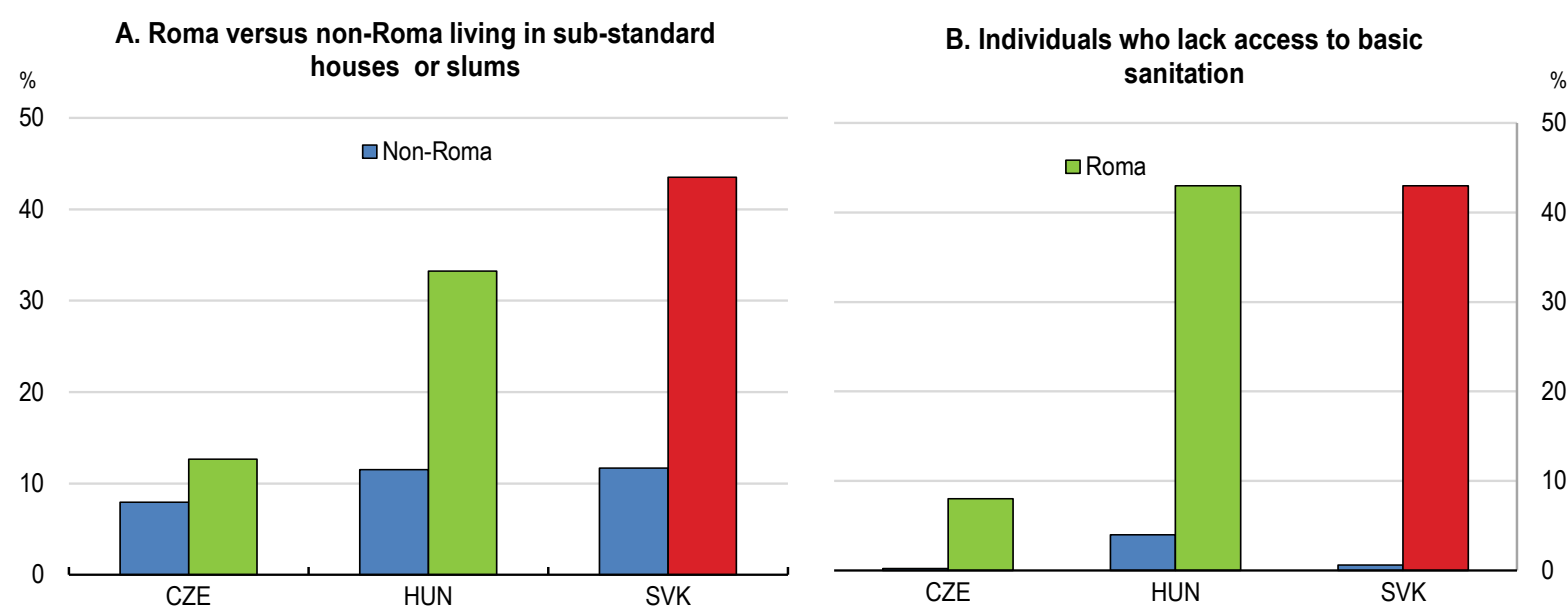

Note: Having a toilet and a shower or bathroom inside the dwelling.

Source: United Nations Development Programme (2016), Database on vulnerability of Roma based on UNDP/WB/EC Regional Roma Survey 2011 and Pilot survey 2011 conducted by the EU Agency for Fundamental Rights (FRA); EU (2016), Second European Union Minorities and Discrimination Survey, Roma - Selected findings, European Union, Agency for Fundamental Rights. 
Moreover, Roma settlements suffer from a lack of basic facilities and access to basic infrastructure. For example, access to clean drinking water through a connection to public water supply is limited (Filčák et al., 2018). Almost half of Roma households live in dwellings without a toilet, shower and bathroom (figure 21, Panel B), and half live in neighbourhoods without a public sewage system. Access to drinking water and wastedisposal services have important repercussions on health and education outcomes.

\section{Formalisation of property rights should be a priority}

A large share of Roma live in informal settings without legal title to the land on which their houses are built. In the past, the Roma minority was subject to forceful population resettlement (Jurova, 2002). During the Second World War and the communist period they were often forced to move to what was at that time considered as state-owned land. However, economic transition followed by the restitution of previously nationalised land significantly changed land ownership in Slovakia. Consequently, in many cases properties on which Roma settlements were built have changed ownership and have been claimed back by their legal owners. Today, only one-third of the Roma own the land on which their houses are built. Another third live on municipal land, while the rest of the Roma settlements are situated on land owned by different owners, hence considered as illegal.

Moreover, as segregated settlements continued to expand, many of the houses were built illegally, as the process of obtaining a building permit is extremely complex (see Chapter 2). Often the only way that poor Roma can afford to build homes is by using makeshift materials that they find, which do not comply with basic construction standards and lack the required permits.

Due to their lack of legal status, municipalities are not allowed to provide infrastructure investment to the settlements, such as roads or water pipe-lines. At the same time, families who lack formal tenure are not eligible to receive a housing allowance. Empirical research indicates that only half of the recipients of assistance in material need are eligible for a housing allowance (Skobla, Csomor and Filadelfiova, 2017). More worryingly, these households risk eviction, as they do not possess sufficient financial means to afford the legalisation process. There have been several landmark cases of forced evictions over the past 10 years. More than 3000 Roma were evicted from their homes between 2010 and 2013, but fewer than 1000 were provided with alternative housing (US, Department of State, 2015).

Therefore formalisation of property rights should be a priority. There is an EU-funded project to provide land-consolidation support. However, support to households and municipalities should be scaled up and should include technical, legal and financial assistance. The Caesar project in Romania or Spissky Hrhov in Slovakia provide examples of good practice (see Box below). They show that with the proper assistance, municipalities can formalise most Roma property rights and provide basic infrastructure for the Roma settlements (Gatti et al., 2016; Musinka, 2012). Based on these examples, government support to municipalities should include technical support to update municipal urban plans, mapping of the informal areas and assessment of property rights. Legal, financial and technical support should be given to Roma households to reach an arrangement with legal landowners in the form of purchase or lease. This legal inclusion should be facilitated by municipalities that can, for example, swap land to ease arrangements. 


\section{Support home improvements}

In addition to formalisation of property rights, public investment in Slovakia's basic infrastructure needs to be strengthened. Several EU-funded projects are devoted to improving the infrastructure in Roma settlements. However, utilisation of these funds is weak, as municipal officials usually lack the technical capacity to apply for these projects or simply choose projects benefiting the general population. Therefore, technical support for the municipalities should increase, and after the end of programming period these programmes should continue under the national budget to support and prioritise the Roma settlements with the worst living conditions.

Past experience with building social housing in Slovakia has not shown positive results. The Housing Development Programme has provided subsidies for local municipalities to acquire municipal rental apartments. It aimed to increase the housing supply, as the share of public housing has been very small. However, providing fully finished public units is costly and complex to manage. Therefore, these programmes can usually target only a small fraction of potential clients. More worryingly, evaluations of these projects have shown that new social housing has deepened segregation as the vast majority of the dwellings are located either in already segregated areas or in other remote locations (Hojsík, 2008; Škobla and Filčák 2016). Also, these flats were soon 'worn out' due to their low quality and overcrowding (Smatanová, 2010). As a result these social housing development projects resulted in further stigmatisation of segregated Roma by the general population.

Therefore, assisted housing has much greater potential to improve housing conditions for the Roma. Assisted housing combines self-help construction with savings and microcredit funding. Building construction takes place under professional surveillance with a focus on gaining professional skills and experience. The social work and assistance to the family are provided throughout the whole saving period and the micro-loan repayment period. Evidence from local NGOs shows that such programmes can significantly improve the living conditions of Roma (World Bank, 2012b). These successful pilot programmes can then be scaled up at the national level.

Another important goal is spatial desegregation. However, this should be based on removing the barriers to voluntary relocation, rather than some forced relocation. This includes improving the access to services and land, enabling Roma to participate in wider society, thus requiring wider support across all policy domains. At the same time the segment of rental housing is small and the share of social housing is negligible.

Some countries, for example, provide social flats in new development projects to foster integration of disadvantaged groups. New development projects in large metropolitan areas such as Vienna, London and New York must devote a small share of their flats for social housing. These flats in the new development projects have regulated rent or prices for socially disadvantaged groups. These measures should be carefully implemented and should be coupled with supportive services to help families adapt to the new community. A successful project in Spain helped Roma families to resettle, providing subsidised rental housing and packages of social support to adjust to the new environment and livelihoods (Gatti et al., 2016). A similar approach has been tested in the Czech Republic. The city of Brno launched the Housing First approach and 50 non-segregated municipal flats have been offered to tenants, who were supervised by social workers with very promising preliminary results (Housing First, 2018). 


\section{Access to health care should be bolstered}

Health-care outcomes of Roma are poor and critical in some areas (Belak et al, 2017; Gatti et al., 2016). The estimated life expectancy is 6 years lower than that of the rest of the population (MoF, 2019). The biggest gap in life expectancy is present in segregated areas of Roma settlements with poor living conditions where these marginalised groups have a life expectancy of barely 53 years, compared with 70 years for non-Roma people (OECD, 2017a; Soltès et al., 2014). The infant mortality rate among the Roma population is almost three times higher than for the non-Roma population (Figure 22). At the same time, the Roma have lower probabilities to live healthy lives as they suffer much more from chronic diseases. For example, while three out of four Slovaks live without any chronic conditions, for Roma women it is $50 \%$ (Sprocha, 2014).

Figure 22. Infant mortality is high for Roma

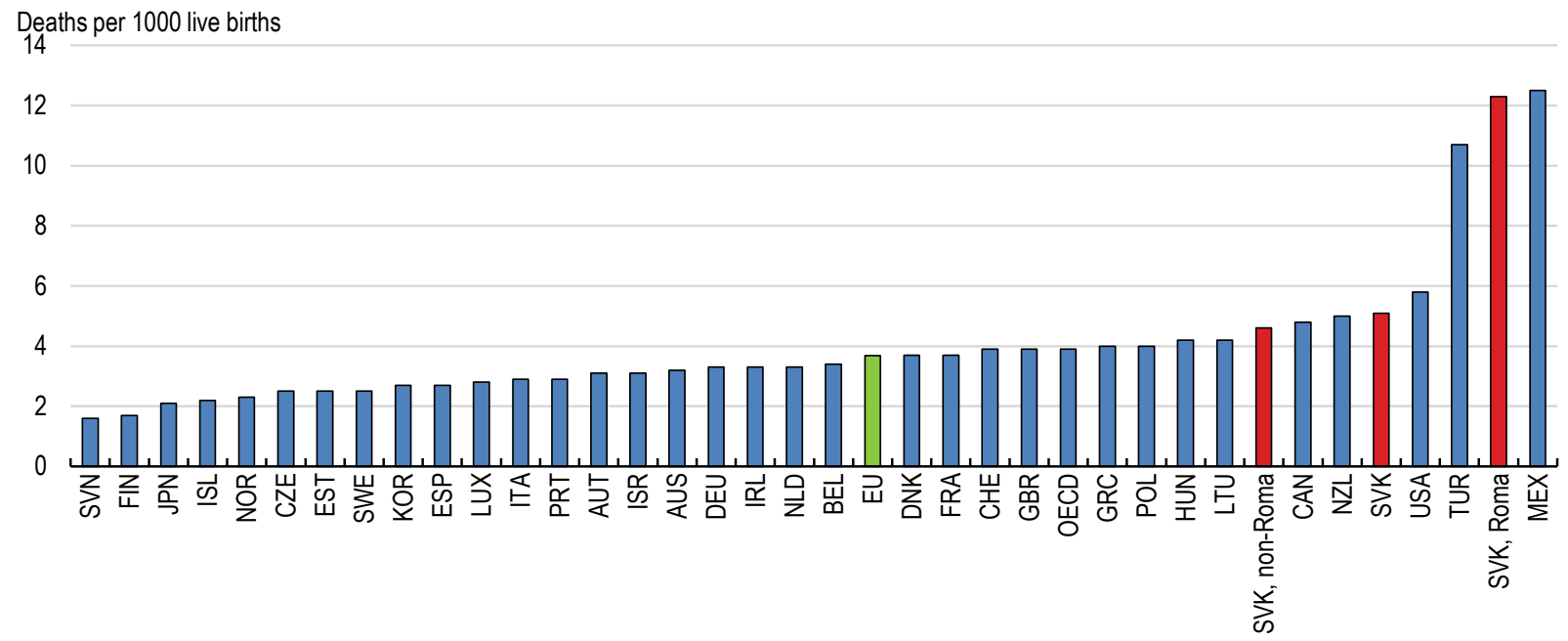

Source: Ministry of Finance (2019), "Spending Review on Groups at Risk of Poverty and Social Exclusion", Expenditure reviews.

StatLink त्ञाज https://doi.org/10.1787/888933902358

The reasons for poor health outcomes include poor living conditions. In segregated settlements the lack of central drinking water or waste disposal helps the spread of infectious diseases, including measles and hepatitis A (EC, 2014a). Outbreaks of epidemics of scabies and lice are common. Moreover, overcrowded places in settlements contribute to the spread of respiratory diseases. It is alarming that $80 \%$ of juvenile tuberculosis patients are Roma (Paraličová et al., 2015). In addition, Roma have more risky lifestyles, with a high prevalence of smoking and unhealthy nutrition practices contributing to their poorer health status and chronic diseases. These reasons for poor health outcomes are exacerbated by their limited access to the health-care system.

\section{Health-care services are available but are used less by Roma}

The availability of health insurance is a major determinant of access to the health-care system. Nearly all Roma citizens $(95 \%)$ are covered by the national basic health insurance, and their coverage is comparable to that of the general population's (FRA, 2016). Also, despite the remoteness of some Roma settlements, the medical services are 
accessible as the distance to the closest critical medical service for the average Roma family is relatively short (1-3 km) (World Bank, 2012a).

However, the Roma use health-care services less than the general population. Half of them do not seek health care when they need it (UNDP, 2012). The low use of health services among Roma is confirmed by system expenditures, which are on average $30 \%$ lower for Roma than non-Roma individuals. Young Roma in particular use health-care services less often (Figure 23). For example, their use by young Roma men (age 5-29) is on average $40 \%$ lower than young non-Roma men. Limited use of health-care services at younger age, including preventive care, can have negative health impacts later in life. Roma women in child bearing age report greater use of health care due to the larger number of children, while most Roma women give birth in hospitals. Nevertheless, after childbirth the use of health care decreases significantly for women and increases again only in older age.

Figure 23. Roma use health care services less often

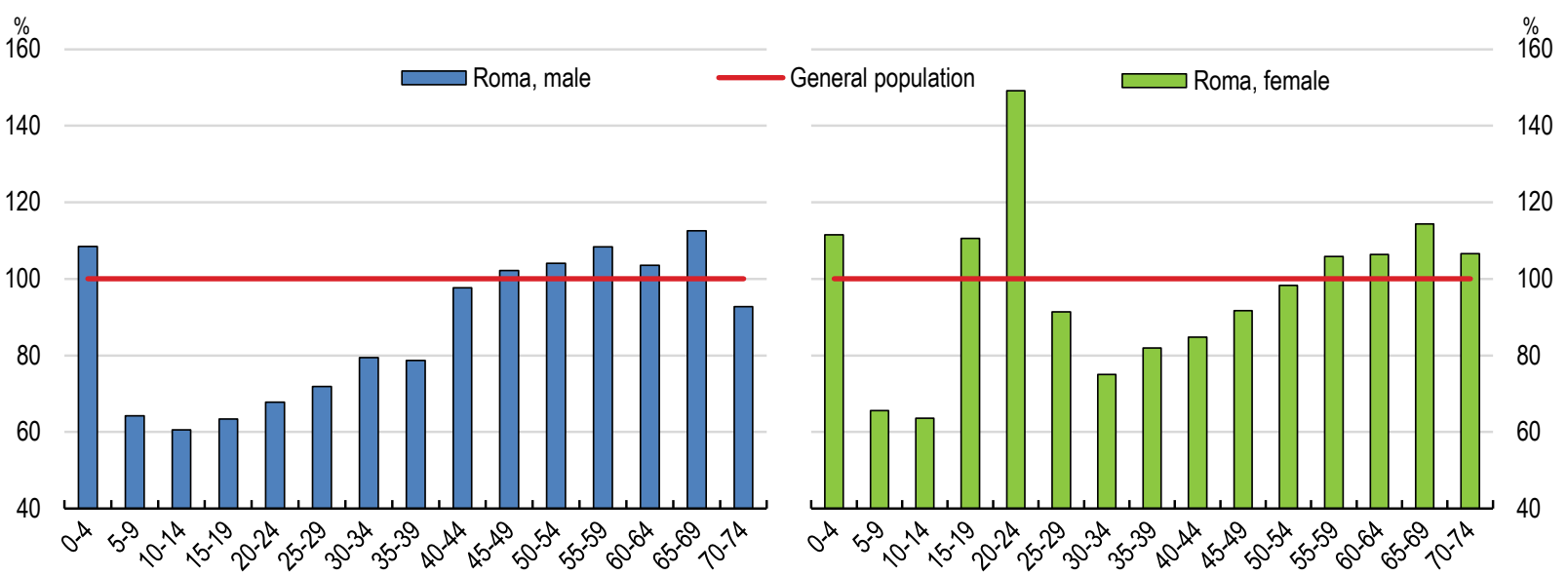

Source: Geva, A., S. Hidas and G. Machlica (2019), "The benefits of social inclusion of Roma in the Slovak Republic", Technical background paper, forthcoming

StatLink त्ञाs https://doi.org/10.1787/888933902377

The reasons for low use of medical services by Roma are related to a number of factors, including significant information barriers and discrimination. Also, limited language and cultural understanding often result in the indirect unavailability of health services. At the same time transport and medical costs represent additional barriers to accessing healthcare services.

\section{Community health workers could help to overcome information barriers}

Roma very rarely use preventative care. For example, check-ups for sugar levels or blood pressure are less frequent among Roma (UNDP, 2012). They tend to use health-care services differently from the non-Roma population, with heavier use of acute hospital services as the result of lower levels of engagement in preventative primary care (World Bank, 2012a; Sheffel, 2005). Roma usually do not seek medical care and wait until health concerns mount significantly before seeking help. Minimal use of preventive care can also be illustrated by vaccination rates, where a little over half of the Slovak Roma population have received some sort of vaccination, compared to up to $99 \%$ in the general population (EC, 2014). The vaccination rate has been improving in recent years. Low levels of preventative care are related to the lack of information among Roma. 
Information barriers are most pronounced in early child development. Roma women have children at much younger ages, and teen pregnancy is common: one-fifth of Roma women have their first child before the age of 18. Most Roma give birth in the hospital, but the frequency of reproductive health check-ups is very low (World Bank, 2012a). Roma children are born with lower birth weights and are less likely to be exclusively breastfed (Gatti et al., 2016). Also, poor diet and nutrition contribute to low immunity and poor growth. The low infant mortality rate among the Roma population can be related to external factors such as diseases or risk behaviour. Therefore, it is of utmost importance to promote greater health knowledge and improve awareness.

The government's Roma health mediators programme aims to strengthen the link between the health services and the Roma population. These Roma health assistants are used to accompany sick people to the doctor, interpret if necessary, contribute to the prevention of infectious diseases and encourage up-take of vaccinations. The direct involvement of Roma mediators in these initiatives is important, because they are better able to target the needs of the community. At the end of 2017 there were some 238 mediators for 261 locations. The available evidence suggests that this programme is the most promising way to effectively address Roma health issues (Gatti et al., 2016).

The programme is currently financed through EU funds, and its future is therefore uncertain. The mediators often have no job security and low salaries. The health-mediator programme should become an integral part of the Ministry of Health budget, and the salary of the mediators should be increased. For example, performance incentive payments could increase the effectiveness and quality of service provision. Further career opportunities should be offered to Roma health assistants who are willing to continue with their studies and develop their carriers in the health sector.

At the same time expansion of these programmes should focus on maternal health information. The current programmes are effective in increasing vaccination coverage and preventive check-ups, but more focus should be added to awareness-raising opportunities for reproductive, maternal and child health services (Gatti et al., 2016). Estimates from the hospitals in East Slovakia indicate that almost $80 \%$ of the hospitalised infants below the age of one are Roma and that many of the diseases can be avoided by raising awareness (Pochova et al., 2011). Although some pilot projects are starting in this area, more mediators specialising in maternal health information would be desirable.

A complementary approach to promote health knowledge and raise awareness is to use the existing entry points in the health-care system. As most Roma women give birth in a hospital, it provides an opportunity to discuss many elements of reproductive health, breastfeeding and post-natal care with the new mother and family members (World Bank, 2012a). Therefore, more training should be allocated to hospital staff to interact more effectively with Roma women. This should be accompanied by distributing materials in Romani regarding nutrition and breastfeeding.

\section{Additional financial support is needed to improve access to health services}

Transport and medical costs represent an additional barrier to access health-care services. The health-care system in the Slovak Republic entitles people to free care. However, the share of total medical costs paid directly by the user is almost one-fifth of total costs, including surcharges for medicines or care not covered. These can represent a significant barrier for disadvantaged households. Indeed, almost one-fifth of the Roma cite financial constraints as a reason not to seek medical services, which is significantly higher than the general population (Figure 24). 
Figure 24. Financial constraints represent a barrier for Roma to seek medical services

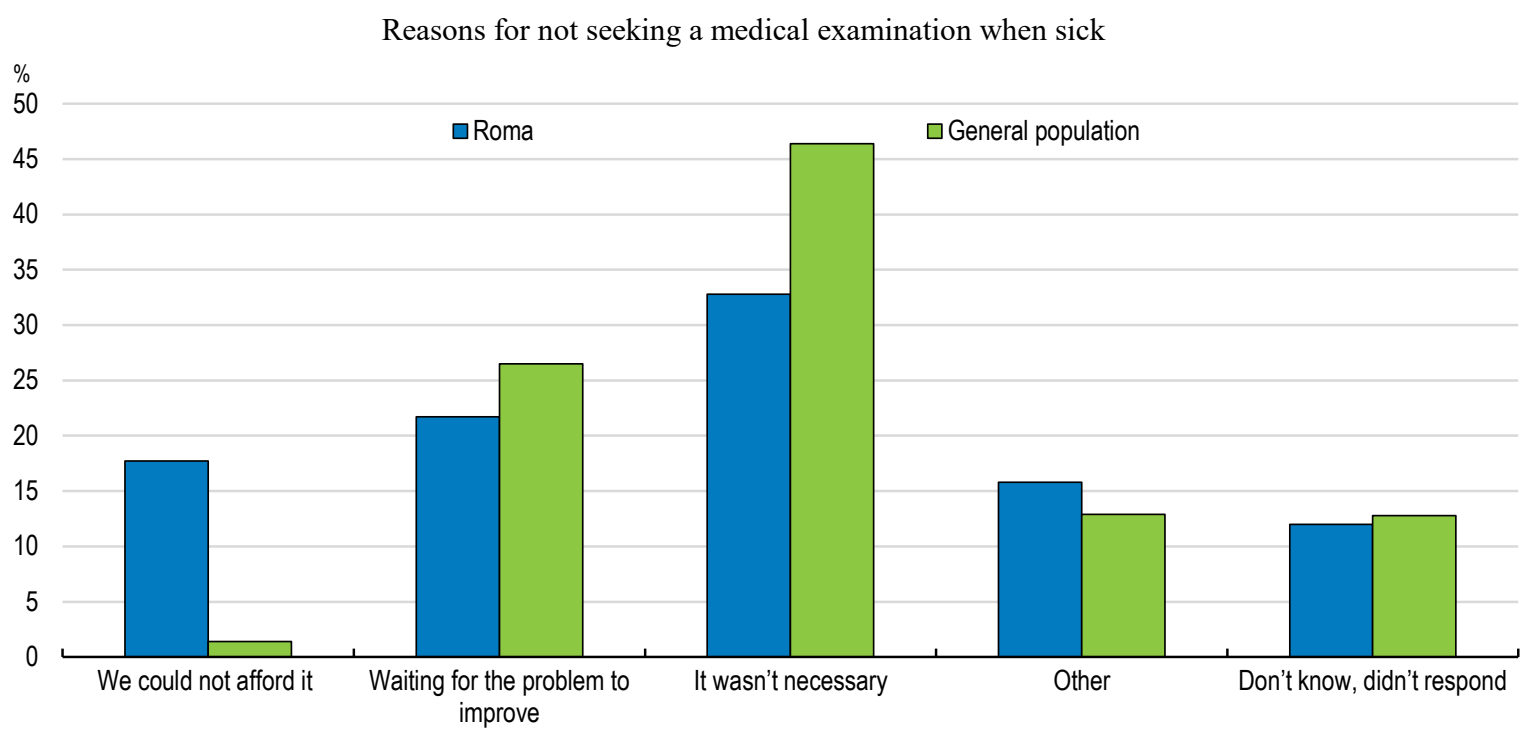

Source: UNDP (2012), "Report on the Living Conditions of Roma households in Slovakia 2010”, Bratislava.

StatLink त्ञाs https://doi.org/10.1787/888933902396

Current legislation exempts pensioners and the disabled from surcharges for medicines. These exemptions should also apply to socioeconomically disadvantaged groups. Many infectious diseases are due to poor living conditions and limited access to clean water. This should be addressed by expanding infrastructure investment in cooperation with other policies. In the meantime, public funding should be found for hygieneepidemiological monitoring of Roma settlements, for corresponding regular disinfection and rat extermination programmes and to support vaccination programmes in the Roma communities, particularly against hepatitis and tuberculosis.

\section{Promoting financial inclusion in the Roma communities}

The Roma are more likely than others to face unexpected expenses due to irregular employment and low income. At the same time they lack access to a broad range of financial services. Only one third of them have bank accounts, and only $10 \%$ have any savings at all (World Bank, 2012a). Even among Roma households that do save, the amount of saving is very low. Roma households are therefore more exposed to income shocks and have less means to invest in education or pay for unexpected health expenses.

Consequently, many Roma are forced to take on debt. Field estimates suggest that more than $70 \%$ of Roma households are currently indebted (Figure 25). However, Roma are poorly positioned to borrow money from commercial institutions because of their economic status and lack of access to information on processes and procedures. Therefore, they borrow small amounts of money through local Roma moneylenders at very high effective interest rates. These usurers have significant social and economic power in the Roma settlements. Field estimates suggest that loan repayments represent up to one-third of monthly household expenditures (UNDP, 2013). Therefore, many Roma become trapped in a cycle of dependence where they do not have any money because they must repay their debt and give all their meagre incomes to the usurers (Hrustic, 2015) or official debt collectors. Heavy indebtedness lowers borrowers' disposable incomes and represents a serious work disincentive, limiting their employment prospects. 
Figure 25. High share of Roma is indebted

Share of Roma households according to the level of debt in euros

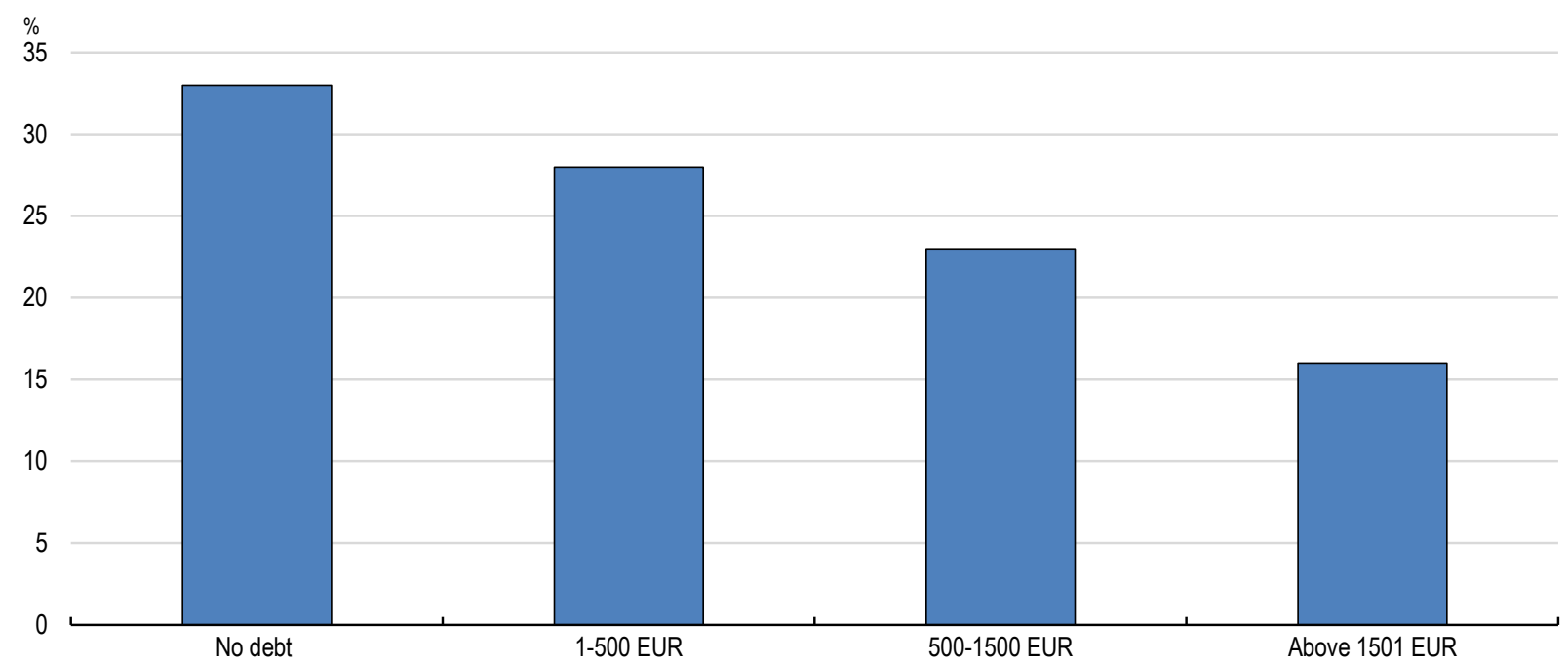

Source: UNDP, (2013) "A situational analysis of selected aspects of living standards of households in marginalised Roma settlements", Bratislava.

\section{StatLink त्गा5 https://doi.org/10.1787/888933902415}

The government should promote financial inclusion by using public social protection payment systems. Roma and non-Roma households receive social protection payments through the post office in cash once a month. Transferring social transfers into personal bank accounts can provide incentives for banks to agree with the government to provide low-cost bank accounts for the poor. This can become an effective tool in the pursuit of public-policy objectives. For example, payments can be disbursed to beneficiaries four times a month, instead of once, to encourage consumption smoothing. Today, many Roma spend most of the payments in the first half of the month following their receipt and then are forced to borrow (Sheffel, 2005). At the same time, introducing electronic payments can provide significant savings for governments. Experience in Brazil and India shows that this measure helped reduce administrative costs significantly (World Bank, 2012b).

Another important tool to enhance financial inclusion is social microcredit, which enables poor Roma households to borrow with much lower interest rates compared to usurers' charges. The development of the Slovak microfinance sector is lagging behind the neighbouring countries, but the scope for microfinance remains limited (World Bank, 2012a). One way forward is to couple the microcredits with saving facilitation and linking saving activities with human development outcomes. For example, ETP an NGO link credit provision for home improvements with saving behaviour. Clients get credit if they prove they can save for a certain amount of time. These programmes can be scaled up and target different development goals. ETP Slovakia disbursed 500 small repayable microloans (1200 Euro) to mostly poor Roma families for small home improvements projects and around $90 \%$ of the funds provided were already paid back.

However, expansion of microfinance schemes should be carefully implemented. Experience from other countries shows that numerous modifications must be made to microcredit practices to adapt to both local conditions and the specific situation of the borrowers. Microcredit lending needs to be coupled with financial education and 
mentoring, and the presence of well-trained field workers is indispensable (EC, 2012). Poor people need careful financial planning to make ends meet with their limited resources. There are some financial education courses that have been developed by an NGO (ETP Slovakia) to teach clients to use their finances wisely and to help them escape from debt trap. Together with the Autonomia Foundation, ETP has been working with standardised financial training modules that have proven successful as entry points into microsavings and microcredit programmes for clients living in marginalised communities (World Bank, 2012a). These programmes should be scaled up, and general financial training should be provided, for example in schools, where they can target teenagers.

\section{A holistic policy approach is needed to address Roma exclusion effectively}

The government should play a key role in enhancing the integration of Roma. However, to be effective, these policies must not act in separate silos. On the contrary, it is important that Roma integration policies take a holistic approach, which will require:

1. Coordinated interventions in different policy areas, as the exclusion is so severe that interventions in one area will not work without others;

2. Involving Roma themselves in policy interventions, to help facilitate dialogue and cooperation between their communities and public institutions;

3. Addressing the attitudes of the general public - without this, integration efforts may not reach their aims.

\section{The current framework goes in the right direction, but could take a more systematic approach}

The current Slovak framework for Roma integration goes in the right direction. It is based on the Strategy for the Integration of Roma 2020, which set out primary goals and action plans in different policy areas (MoI, 2017). Individual ministries are responsible for individual goals which are coordinated by the Plenipotentiary of the Slovak government for Roma communities, who has an advisory role for these matters and provides assistance for projects funded by the European Union.

The main sources of funding specifically targeted at Roma communities are two EUfunded programmes. One finances human resources in the Roma communities, including social workers, health mediators (see below) and the Roma neighbourhood watch. The other finances infrastructure projects. These include building pre-school facilities, community centres and other projects that enable access to basic infrastructure. These EU programmes run throughout the period 2014-20 with estimated costs of EUR 435 million (an average per year of $0.07 \%$ of Slovak GDP).

Although EU-funded programmes have increased the resources targeted at Roma integration, they remain small. Only $30 \%$ of the municipalities with Roma population have so far applied for these EU funds. Many projects were intended as pilots to test different approaches and then expand the successful ones. However, none of them have so far been incorporated into the national budget. Individual projects usually run only for two or three years, followed by lengthy breaks before successor EU-funded programmes start up. This creates serious disruptions in public support for Roma communities: for example, a social worker may lose their job and have to move elsewhere before funding is renewed. At the same time the future of these programmes is uncertain as EU funds 
may come to an end in 2020. Consequently these funds cannot be relied upon for a systematic and sustainable policy approach to Roma integration.

At the same time, monitoring and evaluation of the current framework is very limited. EU-funded projects are evaluated using field interviews, but in the Slovak Republic there is no regular monitoring of the overall situation of the Roma (see Annex A). This seriously limits efforts to improve programme design and to raise the effectiveness of public integration policies explicitly targeting the marginalised Roma.

\section{Stronger coordination of policies for Roma communities is needed}

Successful integration will require coordinated interventions in different policy areas including: education, labour market policies, health care, housing, and financial inclusion. In New Zealand, a multi-pronged approach is laid out in the treasury's "Living Standards Framework" to address well-being gaps for low socio-economic households, including many Māori and Pasifika people (OECD, 2015a).

Implementing interventions in an integrated manner requires a designating body that purposefully coordinates different policies. This includes building networks and creating a common working platform for the relevant stakeholders at the local level. In the current framework this position is held by the Plenipotentiary, but its mandate is weak, as it has only an advisory role with limited power to influence other ministries. However, the present situation of the Roma calls for urgent action, requiring stronger institutional and political authority for the Plenipotentiary. A model could be the Deputy Prime Minister's Office for Investment and Informatization in the Slovak Republic, which is a crosscutting ministry coordinating other ministries in the area of investments. The same approach could be applied to the area of Roma integration. Strengthening the Plenipotentiary's position in the institutional hierarchy can help better coordinate all the relevant actors so that they work together. This includes municipalities given the Plenipotentiary's strong local network. Mayors have to take initiative as they play an important role for policy implementation.

The Plenipotentiary should also be mandated, and resourced, to collect data and monitor the situation of the Roma. Suitable data collection and rigorous analysis are particularly important to inform individual line ministries and coordinate the policy response appropriately. Household survey data in marginalised Roma communities should be collected on an annual basis and impact evaluations can help identify the most costeffective actions.

\section{Box 4. Successfully coordinated policy intervention at the local level}

Spissky Hrhov is a village known as an example of successful Roma integration. Twenty years ago, the Roma represented almost half of the population, most of them lived in ruined houses, without electricity and one-fifth of the children were in special schools. Today, most of the Roma community members are employed, enjoying a good living standard and are integrated with the wider community. Roma pupils do not only finish their primary education, but also continue on to grammar school or vocational school in the district (CoE, 2012).

The process of the integration has started 20 years ago. From the beginning, the municipality identified three key areas of development, which were addressed simultaneously i) education, ii) employment iii) housing (Musinka, 2012). Key 
stakeholders attached to these areas were identified and engaged: the local administration, social workers, employers, local school and the community centre.

Establishing a local municipal company helped employ some Roma from the local community. This company is run by the municipality and uses local materials and employs local residents. It uses its profits to address the specific social issues that the local community is facing. At the same time the municipality helped with formalisation of property rights (see above). Land regularization was followed by the housing projects and municipality has built its own social flats, partly financed by the municipal company. Renters were carefully selected and supported by local social and community workers. The school closely cooperate with Roma families and the educational process is provided by qualified teachers, some of who speak Romani. The Roma community was engaged in the implementation of projects and participated in home construction works and other activities (World Bank, 2014a).

\section{More trained Roma personnel are needed}

As much as possible, programmes to improve the situation of the Roma should be designed in consultation with the communities they are intended to help. This would reduce the risk that they are imposed from outside rather than facilitating contacts that Roma themselves wish to make.

There are already some successful EU funded pilot projects which rely on direct involvement of Roma mediators, who are better able to understand the needs of the community than outsiders. For example, trained Roma health assistants work as a bridge between the community and the local health authorities to improve access to health care for Roma. They accompany sick people to the doctor, interpret if necessary and encourage up-take of vaccinations (see above). International experience indicates that, over the years, mediators have effectively mitigated some of the challenges faced by Roma when seeking health care (OSF, 2014). Another example is Roma Civil Neighbourhood Watch, in which Roma act as mediators with police officers, who may otherwise be seen as repressive outsiders. They patrol around their local settlement and help the police solving difficult problems and conflict situations.

More trained personnel within individual ministries and local agencies are also needed, who can facilitate dialogue and cooperation between the Roma populations and public institutions. It is important to integrate successful EU-funded programmes into national policies and scale up, so that Roma health assistants and Roma Neighbourhood Watch can become an integral part of public services. In addition, Roma mediators in different areas of public services should be explored, for example Roma teaching assistants or Roma social workers. These assistant professions should be provided with a clear career path to regular mainstream professions. For example, Roma health care assistants should be provided with the possibility and additional training to continue with their carriers in the healthcare sector and become nurses or carers.

\section{Addressing the attitudes of the general population}

Roma inclusion efforts may be more effective if they take into account the attitudes of the general public and especially if they can reduce the general animosity and mistrust between the Roma and non-Roma. Therefore, policy changes towards Roma integration should go hand in hand with work to address prejudice against the Roma among parts of the majority population. 
In recent years progress has been made in putting together a legal and policy framework to tackle discrimination against the Roma. However, outreach to the Roma groups remains ineffective: most Slovak Roma ( $80 \%$ of all those surveyed) are unaware of the existence of any organisations that can offer support or advice to people who have suffer from discrimination (FRA, 2016), and half of all Roma are unaware of antidiscrimination laws (Figure 26).

Figure 26. Awareness among Roma of laws prohibiting discrimination (\%)

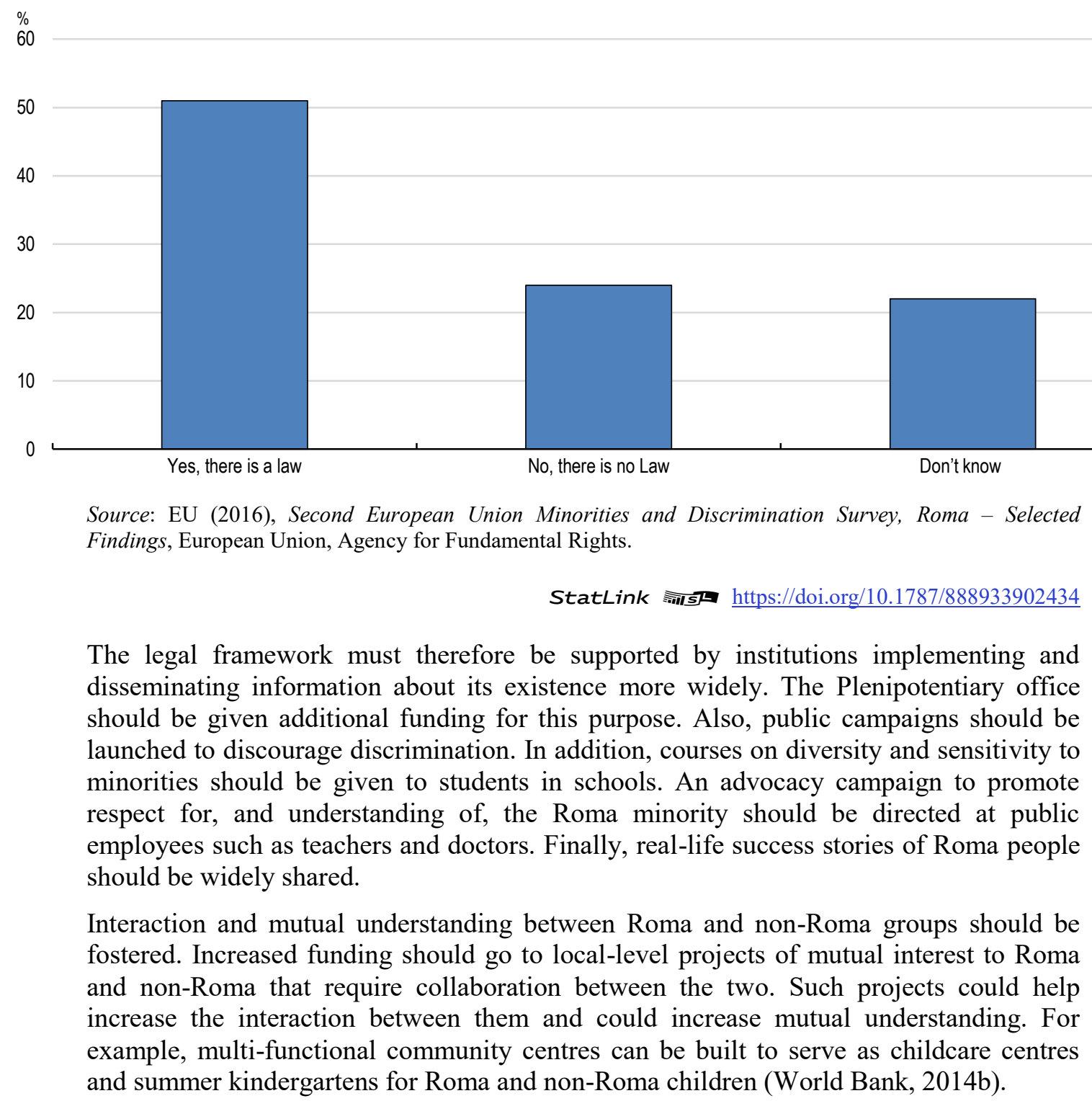




\section{Recommendations to enhance social inclusion of Roma}

(Key recommendations included in the Executive Summary are in bold italics)

Promoting an integrated approach to Roma inclusion

- Give the office of the Plenipotentiary a bigger role in coordinating national policies and ensuring integrated provision of public services to Roma where they live.

- Involve Roma in the development and operation of integrated health, education and employment services.

- Scale up successful EU-funded pilot programmes, such as community centres and health mediators, and ensure sustained financing through the national budget.

- Develop statistics to monitor and evaluate the effectiveness of Roma support programmes.

Enhancing Roma inclusion in education

- Continue to expand the provision of high-quality early education and care, engage with parents to advertise its benefits, and remove financial barriers to attendance.

- Provide more funding for disadvantaged schools, particularly for Roma teaching assistants and higher salaries for teachers teaching in disadvantaged schools.

- Increase the number of teaching assistants speaking Roma, and provide Slovak language support for Roma children.

- Reduce the participation of Roma in special schools by better diagnostics and outreach towards Roma parents.

Strengthening Roma access to the labour market

- Increase spending on those training programmes for the unemployed of proven effectiveness.

- Design and develop a network of second-chance education providers.

Improving Roma living conditions

- Provide support to formalisation of Roma property rights, including legal, financial and technical support to municipalities and Roma households.

- Scale up the housing assistance microfinancing project to the national level.

- Strengthen public investment in basic infrastructure in Roma settlements.

Bolstering Roma access to health care

- Expand health-care mediator programmes, with more mediators specialising in maternal health information and preventive check-ups for mothers.

- Provide exemptions from surcharges for medicines for disadvantaged groups.

- Provide funding for vaccination programmes, regular disinfection and rat extermination programmes in Roma settlements.

Promoting financial inclusion in the Roma communities

- Introduce a social micro-credit loan scheme that is coupled with financial education courses for marginalised communities. 


\section{Bibliography}

Amnesty International and European Roma Rights Centre (2017), "A lesson in discrimination segregation of Romani children in primary education in Slovakia", www.errc.org/cms/upload/file/report-lesson-indiscrimination-english.pdf.

Belak, A., Geckova, A. M., van Dijk, J. P. \& Reijneveld, S. A. (2017): Health-endangering everyday settings and practices in a rural segregated Roma settlement in Slovakia: A descriptive summary from an exploratory longitudinal case study. BMC Public Health 17(1): 128

Blass, N. (2017), "The Scholastic Achievements of Arab Israeli Pupils", Taub Center for Social Policy Studies in Israel, http://taubcenter.org.il/the-scholastic-achievements-of-arab-israeli-pupils/.

Card, D., J. Kluve and J. Weber (2015), "What Works? A Meta Analysis of Recent Active Labour Market Program Evaluations", NBER Working Papers, No. 21431, www.nber.org/papers/w21431.

Chetty, R., J. Friedman and J. Rockoff (2014), "Measuring the Impacts of Teachers I: Evaluating Bias in Teacher Value-Added Estimates", American Economic Review, Vol. 104, No. 9.

Corak M., (2013), "Income Inequality, Equality of Opportunity, and Intergenerational Mobility" IZA, Discussion Paper, No. 7520, Bonn, http://ftp.iza.org/dp7520.pdf

CoE (2017), "Fighting school segregation in Europe through inclusive education: a position paper " Council of Europe- Commissioner for Human Rights, Strassbourg, https://rm.coe.int/fighting-schoolsegregationin-europe-throughinclusive-education-a-posi/168073fb65

CVEK (2018), "Civil Society Monitoring Report on Implementation of the National Roma Integration Strategy in Slovakia" http://cvek.sk/wpcontent/uploads/2018/04/RCM 2017 Slovakia_EC approved.pdf

CVTI (2014), Štatistická ročenka - špeciálne školy, Centrum vedecko - technických informácii SR, Bratislava, http://www.cvtisr.sk/cvti-sr-vedecka-kniznica/informacie-o-skolstve/statistiky/statistickarocenka-publikacia/statisticka-rocenka-specialne-skoly.html?page_id=9600

CoE (2012), "Slovakia -the primary school in Spissky Hrhov: an example of inclusive education" Council of Europe, Good practice 24, http://goodpracticeroma.ppa.coe.int/en/pdf/560

Duell, N., P. Tergeist, U. Bazant and S. Cimper (2010), “Activation Policies in Switzerland”, OECD Social Employment and MigrationWorking Papers, www.oecd.org/els/workingpapers.

EC (2012) "Social microcredit, self-employment and Roma inclusion" Lessons of Kiútprogram, a social microcredit pilot and policy recommendations for the new Structural Funds period, Brussels.

EC (2014), "Roma Health Report", European Commission, https://ec.europa.eu/health//sites/health/files/social_determinants/docs/2014_roma_health_report en.p df

EC (2015), "Cost-Benefit Analysis of Remedial Intervention for the Long-TermUnemployed", Brussels.

EC (2016) "Study on the Diversity within the Teaching Profession with Particular Focus on Migrant and/or Minority Background" European Commission, Directorate-General for Education, Youth, Sport and Culture Education and Training, Brussels, http://ec.europa.eu/dgs/education_culture/repository/education/library/study/2016/teacherdiversity en.pdf

European Commission/EACEA/Eurydice (2016), "Structural Indicators on Early Childhood Education and Care in Europe - 2016" Eurydice Report. Luxembourg: Publications Office of the European 
Union, http://eurydice.indire.it/wpcontent/uploads/2017/02/Early Childhood Education and Care .pdf

EC (2017a), The 2018 Ageing Report, European Commission, November, Brussels, https://ec.europa.eu/info/sites/info/files/economy-finance/ip065 en.pdf

EC (2017b), "Playgroups for Inclusion", European Commission Programme for Employment and Social Solidarity - PROGRESS (2007-2013) (Grant agreement VS/2014/0418), https://www.uc.pt/fpce/investigacao/projetos/GeneralPresentationPfI

EC (2017c), "Preparing teachers for diversity" European Commission, Directorate-General for Education, Youth, Sport and Culture Education and Training, Brussels, https://publications.europa.eu/en/publication-detail/-/publication/b347bf7d-1db1-11e7-aeb301aa75ed71a1/language-en

EC (2018), "Civil Society Monitoring Report on Implementation of the National Roma Integration Strategy in Slovakia", European Commission, Centre for the Research of Ethnicity and Culture Roma Advocacy and Research Centre, 2018, Brussels, http://cvek.sk/wpcontent/uploads/2018/04/RCM_2017_Slovakia_EC_approved.pdf

Elacqua, G. (2012), "The impact of school choice and public policy on segregation: Evidence from Chile", International Journal of Educational Development, Vol. 32, No. 3, pp. 444-53, https://doi.org/10.1016/j.ijedudev.2011.08.003.

Equality (2011), "From segregation to inclusion: Roma pupils in the UK" Roma education fund, http://equality.uk.com/Education_files/From\%20segregation\%20to\%20integration_1.pdf

Eurobarometer (2012), "Discrimination in the EU in 2012", Special Eurobarometer 393, http://ec.europa.eu/commfrontoffice/publicopinion/archives/ebs/ebs_393 en.pdf

EASI (2016), „Financing of Inclusive Education: Mapping Country Systems for Inclusive Education“ European Agency for Special Needs and Inclusive Education, Odense, Denmark, https://www.european-agency.org/sites/default/files/Financing_of Inclusive Education_EN.pdf

Filčák, R., M. Szilvasi andD. Škobla (2018) "No water for the poor: the Roma ethnic minority and local governance in Slovakia, Ethnic and Racial Studies, Vol. 41. No. 7, , DOI: 10.1080/01419870.2017.1291984

FRA, (2016), "Second European Union minorities and discrimination survey" European Agency for fundamental rights, Luxembourg, https://fra.europa.eu/en/publication/2016/eumidis-ii-roma-selectedfindings

Friedman, E., E. Gallová Kriglerová, , M. Kubánová, , M. Slosiarik, (2009), ”School as a Ghetto Systemic Overrepresentation of Roma in Special Education in Slovakia" REF, https://www.romaeducationfund.org/sites/default/files/publications/school as ghetto.pdf

FSG (2007), “Zdravotná starostlivost’ v sociálne vylúčených rómskych komunitách”, Fundación Secretariado Gitano, Madrid, http://ec.europa.eu/health/ph_projects/2004/action3/docs/2004_3_01_manuals_sk.pdf

Gallová Kriglerová, E., Gažovičová, T., Kadlečikva, J. a Lajčáková, J. (2012), „Škola pre všetkých?“ CVEK, Bratislava, http://cvek.sk/skola-pre-vsetkych-inkluzivnost-opatreni-vo-vztahu-k-romskymdetom/

Gatti , R., S. Karacsony, I. Sandor, K. Anan, C. Ferré and C. de Paz Nieves (2016), Being Fair, Faring Better, Promoting Equality of Opportunity for Marginalized Roma, World Bank, Washington, DC 
Geva, A., S. Hidas and G. Machlica (2019), "The benefits of social inclusion of Roma in the Slovak Republic", Technical background paper, forthcoming.

Heckman, J. et al. (2009), "The Rate of Return to the High/Scope Perry Preschool Program", Journal of Public Economics, 94(1-2), pp. 114-128.

Housing First (2018), project website, https://hf.socialnibydleni.org/rapid-re-housing-brno (accessed 11. November 2018)

Hsieh, CT., E. Hurst, P.J. Klenow, Ch.I. Jones (2018), "The Allocation of Talent and U.S. Economic Growth", NBER Technical Report, http://faculty.chicagobooth.edu/erik.hurst/research/HHJK.pdf

Hidas, S., P. Harvan and K. Val'ková (2016), "Vel'a práce na úradoch práce: Efektivita a účinnost' služieb zamestnanosti", www.finance.gov.sk/Default.aspx? CatID $=11228$

Hojšík, M. F. (2008), "Evaluation of the municipal rental housing programme in Roma settlements", MilanŠimečka Foundation, http://www.nadaciamilanasimecku.sk/fileadmin/user_upload/dokumenty/Ine/Evalu_cia_FINAL.pdf

Hrustic, T. (2015) Usury among the Slovak Roma: Notes on Relations between Lenders and Borrowers in a Segregated Taboris. In M. Brazzabeni, M. I. Cunha, M. Fotta : Gypsy Economy - Romani Livelihoods and Notions of Worth in the 21st Century., Berghahn, , pp.31-48

Jurova A. (2002) "Historical development of Roma settlements in Slovakia and the issue of ownership of land ("illegal settlements")" Individual and Society, 2002, Vol. 5, No. 4.

http://www.clovekaspolocnost.sk/sk/rocnik-5-rok-2002/4/studie-a-clanky/historicky-vyvoj-romskychosad-na-slovensku-a-problematika-vlastnickych-vztahov-k-pode-nelegalne-osady/

Kertesi, G. and G. Kézdi (2014), "On the test score gap between Roma and non-Roma students in Hungary and its potential causes", Budapest Working Papers on the Labour Market, No. BWP $2014 / 1$.

Kureková, L. and N. Duel (2013), “Activating Benefit in Material Need Recipients in the Slovak Republic”, CELSI Research Report, No 3.

Machlica, G., S. Hidas and B. Žúdel (2014), "Unemployment in Slovakia”, Institute for Financial Policy, Economic Analysis, Policy Paper, No. 30, Bratislava, www.finance.gov.sk/en/Components/CategoryDocuments/s_LoadDocument.aspx? categoryId=698\&d ocumentId $=605$ ).

Marcincin, A. and L. Marcincinová (2009), The Cost of Non-Inclusion. The Key to Integration is Respect for Diversity, Open Society Foundation, Bratislava.

MoF (2016), "Vel’a práce na úradoch práce: Efektivita a účinnost' služieb zamestnanosti" Institut Financnej Politiky, Ministerstvo Financii Solovenskej Republiky, http://www.finance.gov.sk/Default.aspx?CatID $=11228$

MoF (2018), "Inklúzia Rómov je celospoločenskou výzvou“ Inštitút finančnej politiky, Ministerstvo financií, 2018 august, http://www.finance.gov.sk/Default.aspx?CatID=11824

MoF (2019), "Spending Review on Groups at Risk of Poverty or Social Exclusion", Expenditure reviews, https://www.finance.gov.sk/sk/financie/hodnota-za-peniaze/revizia-vydavkov/reviziavydavkov.html

MoI (2017), "Updated action plans of the Slovak Republic Roma integration strategy by 2020, for the years 2016 - 2018", Ministry of Interior, https://minv.sk/?strategia-pre-integraciu-romov-do-roku$\underline{2020}$ 
MŠVVŠ SR (2017), "Správa o hospodárení za rok 2016” MŠVVŠ SR, Bratislava, https://www.minedu.sk/data/att/11896.pdf

Jurášková, E .Kriegelová and J. Rybová (2004), Atlas rómskych komunit, Bratislava, Úrad vlády SR.

Musinka et al. (2012), (Ne)legalne osady, Prešovská Univerzita v Prešove, Ústav Rómskych štúdii,

Musinka A. (2012), The things that worked, Prešovská Univerzita v Prešove, Ústav Rómskych štúdii, http://ec.europa.eu/regional_policy/archive/conferences/roma2013/doc/things_that_worked.pdf

Nusche, D. (2009), "What Works in Migrant Education?: A Review of Evidence and Policy Options", OECD Education Working Papers, No. 22, OECD Publishing, Paris. http://dx.doi.org/10.1787/227131784531

OECD (2011), Investing in early childhood education and care (ECEC), OECD Publishing, Paris, https://www.oecd.org/education/school/48980282.pdf

OECD (2012), Equity and Quality in Education: Supporting Disadvantaged Students and Schools, OECD Publishing, Paris, http://dx.doi.org/10.1787/9789264130852-en.

OECD (2013), “Tackling long-term unemployment amongst vulnerable groups”, OECD Publishing, Paris, http://www.oecd.org/cfe/leed/Tackling\%20Long_Term\%20unemployment \%20WP covers.pdf

OECD (2014a), "How Much Are Teachers Paid and How Much Does it Matter?", Education Indicators in Focus, No. 21, OECD Publishing, Paris, http://dx.doi.org/10.1787/5jz6wn8xjvvh-en.

OECD (2015a), OECD Economic Surveys: New Zealand 2015, OECD Publishing, Paris. http://dx.doi.org/10.1787/eco_surveys-nzl-2015-en

OECD (2015b), "Helping immigrant students to succeed at school - and beyond" OECD Publishing, https://www.oecd.org/education/Helping-immigrant-students-to-succeed-at-school-and-beyond.pdf

OECD (2016), Low-Performing Students: Why They Fall Behind and How To Help Them Succeed, PISA, OECD Publishing, Paris, https://doi.org/10.1787/9789264250246-en.

OECD (2017a), OECD Economic Surveys: Slovak Republic 2017, OECD Publishing, Paris. http://dx.doi.org/10.1787/eco surveys-svk-2017-en

OECD (2017b),OECD Family database, OECD - Social Policy Division - Directorate of Employment, Labour and Social Affairs; http://www.oecd.org/els/soc/PF3_4_Childcare_support.pdf

OECD (2017c), OECD Economic Surveys: New Zealand 2017, OECD Publishing, Paris. http://dx.doi.org/10.1787/eco_surveys-nzl-2017-en

OECD (2017d), The Funding of School Education: Connecting Resources and Learning, OECD Publishing, Paris. http://dx.doi.org/10.1787/9789264276147-en

OECD (2018a), A Broken Social Elevator? How to Promote Social Mobility, OECD Publishing, Paris, https://doi.org/10.1787/9789264301085-en.

OECD (2018b), Engaging Young Children: Lessons from Research about Quality in Early Childhood Education and Care, Starting Strong, OECD Publishing, Paris. http://dx.doi.org/10.1787/9789264085145-en

OECD (2018c), OECD Economic Surveys: Canada 2018, OECD Publishing, Paris. http://dx.doi.org/10.1787/eco_surveys-can-2018-en

OECD (2018d), OECD Economic Surveys: Israel 2018, OECD Publishing, Paris. http://dx.doi.org/10.1787/eco surveys-isr-2018-en 
OSF (2014), "Roma Health Mediators: Advancing the health and rights of Roma communities", Open Society Fund, https://ec.europa.eu/epale/en/resource-centre/content/roma-health-mediatorsadvancing-health-and-rights-roma-communities

Paraličová Z., P. Jarčuška and D. Hudáčková, (2015), "Infekčné choroby u marginalizovaných skupín Rómov žijúcich v osadách", Via Practica, Vol.12 No. 3 pp.: 111-113, http://www.viapractica.sk/index.php?page=pdf_view\&pdf_id=7528\&magazine id=1

Pochová, D., M. Timurová and M. Koval (2011), "Vplyv dojčenia na zdravie detí”, Klinika pediatrie, Prešov.

Rizman, J., (2018), "Jablko padá d'aleko od stromu" Institute for Financial Policy, Ministry of Finance of the Slovak Republic, Policy Brief, No 09. http://www.finance.gov.sk/Default.aspx?CatID=11756

RECI (2018), “Inklúzia Rómov od raného detstva” Joint project Open Society Foundations, Rómsky vzdelávací fond and UNICEF, Bratislava, http://www.eduroma.sk/wpcontent/uploads/2018/01/RECI_Slovak-Republic-report_SLO-01-12-2018-highres.pdf

Ripka, Š. (2016), “Local engagement for Roma inclusion” Locality study Brno (Czech Republic), European agency for Fundamental Rights 2016, Case Study template.

Rosinský, R., Matulayová T. and J. Rusináková (2015), “Evaluačná správa Národný projekt Komunitné centrá” Implementačná agentúra MPSVR SR, Bratislava, https://www.ia.gov.sk/data/files/np_kc/Dokumenty/V_stupy/Evaluacna_sprava_november_NP_KC_fi $\underline{\text { n.pdf }}$

Santiago, P. et al. (2016), OECD Reviews of School Resources: Slovak Republic 2015, OECD Reviews of School Resources, OECD Publishing, Paris. http://dx.doi.org/10.1787/9789264247567-en

Schacter, J. and Y.M. Thum (2004), "Paying for high- and low-quality teaching", Economics of Education Review, Vol. 23, No. 4, pp. 411-30.

Scheffel, D. (2005) Svinia in Black and White: Slovak Roma and their Neighbours, University of Toronto Press.

Skobla D., G. Csomor, J.Filadelfiova, (2017) "Changes in the system of assistance in material need and the impact of changes in the provision of housing allowance since 2014 in Slovakia. IVPR 2017. DOI: $10.13140 /$ RG.2.2.27502.00325

Škobla D., R. Filčák (2016): Infrastructure in Marginalised Roma Settlements: Towards a Typology of Unequal Outcomes of EU Funded Projects /. In Sociológia - Slovak Sociological Review. ISSN 00491225. - Roč. 48, č. 6 (2016), s. 551-571.

Smatanova, K. (2010), "Social, standards and housing for Slovak Roma" ETH Zurich https://www.ethz.ch/content/dam/ethz/special-interest/conference-websites-dam/no-cost-housingdam/documents/Smatanova final.pdf

SGI (2013), "Cestovná mapa pre riešenia problému nadmerného zastúpenia rómskych detí v špeciálnom školstve - analýza realistických krokov" Inštitút pre dobre spravovanú spoločnost', http://www.governance.sk/gov_project/cestovna-mapa-pre-riesenia-problemu-nadmernehozastupenia-romskych-deti-v-specialnom-skolstve-analyza-realistickych-krokov/

Šoltés, V., M. Šoltés and B. Gavurová (2014), "Vývoj mortality v regiónoch s vysokou koncentráciou rómskeho obyvate stva" ("Mortality development in the regions of high concentration of Roma population”), in Nerovnos a chudoba v Európskej únii a na Slovensku, 22-24 October, Košice.

Sprocha, B. (2014), Reprodukcia rómskeho obyvatel'stva na Slovensku a prognóza jeho populačného vývoja, INFOSTAT - Výskumné demografické centrum. 
SSI (2016) “Správa o stave vytvárania predpokladov na zabezpečenie inkluzívneho vzdelávania pre žiakov zo sociálne znevýhodňujúceho prostredia v základných školách“ Štátna školská inšpekcia, Bratislava, https://www.ssiba.sk/admin/fckeditor/editor/userfiles/file/Dokumenty/SPRAVY/2017/UZP Inkluzia ZS_2016_2017.pdf

Schweinhart, L. (2006), "Preschool Programmes", Encyclopedia on Early Childhood Development, Centre of Excellence for Early Childhood Development, Montreal

TALIS (2013), Country profile Slovak Republic", OECD Publishing, Paris, http://www.oecd.org/slovakia/TALIS-Country-profile-Slovak-Republic.pdf

Tergeist, P. and D. Grubb (2006), "Activation Strategies and the Performance of Employment Services in Germany, the Netherlands and the United Kingdom", OECD Social, Employment and Migration Working Papers, No. 42, OECD Publishing, Paris. http://dx.doi.org/10.1787/341116536484

To dá rozum, (2018), “Vyrieši povinné predškolské vzdelávanie nízky počet detí v MŠ?” Denník N, Bratislava, https://dennikn.sk/blog/1107404/vyriesi-povinne-predskolske-vzdelavanie-nizky-pocetdeti-v-materskych-skolach/

UNDP (2012), "Report on the Living Conditions of Roma households in Slovakia 2010", Bratislava, http://www.eurasia.undp.org/content/dam/rbec/docs/Report-on-the-living-conditions-of-Romahouseholds-in-Slovakia-2010.pdf

UNDP (2013) "A situational analysis of selected aspects of living standards of households in marginalised Roma settlements, Bratislava, http://www.ivo.sk/buxus/docs//publikacie/subory/A_Situational Analysis of Selected Aspects Mar ginalized_Roma_Settlements.pdf

UNDP (2014), Atlas rómskych komunít na Slovensku 2013, Regionálne centrum Rozvojového programu OSN pre Európu a Spoločenstvo nezávislých štátov.

US Department of state (2015), "Slovakia 2015 human rights report" US Department of State, Bureau of Democracy, Human Rights and Labor, Country Reports on Human Rights Practices for 2015, https://www.state.gov/documents/organization/253111.pdf

World Bank (2012a), "Diagnostics and Policy Advice on the Integration of Roma in the Slovak Republic. Economic Cost of Exclusion, Employment and Social Protection, Financial Inclusion, Education, Housing, Health, Monitoring and Evaluation, EU Financing”, World Bank, Washington, DC. http://documents.worldbank.org/curated/en/570461468303056342/Main-report

World Bank (2012b), "Reducing Vulnerability and Promoting the Self-Employment of Roma in Eastern Europe Through Financial Inclusion," "World Bank, Washington, DC

http://documents.worldbank.org/curated/en/157071468249644850/pdf/723310WP0P127200financial 0inclusion.pdf

World Bank (2014a) "Handbook for improving the living conditions of Roma" Washington, DC: World Bank Group. http://documents.worldbank.org/curated/en/426791468030548664/Handbook-forimproving-the-living-conditions-of-Roma

World Bank (2014b), "Diagnostics and policy advice for supporting Roma inclusion in Romania" Washington, http://www.worldbank.org/content/dam/Worldbank/document/eca/romania/OutputEN.pdf 


\section{Annex 1.A. Data on Roma}

Most data regarding the Roma is surrounded by uncertainty, therefore should be treated with caution. At present official statistics do not provide reliable and accurate data on Roma. Data collection based on ethnicity is prohibited in the Slovak Republic. Moreover, the usual self-identification questions, such as in the census, are significantly biased and differ from experts' estimates (Ivanov et al., 2012). The most obvious explanation is an unwillingness to reveal one's Roma identity due to the stigma associated with "belonging to Roma" (Makkonen, 2007). Therefore, the Roma respondents in the self-identifying questionnaires tend to choose Slovak ethnicity instead, which understates the true size of the Roma community. According to the latest official Census data, the share of the Roma population in the population is only $2 \%$, which is in stark contrast with experts' estimates that are higher by as much as four-fold (Figure A.1).

Figure A.1. Estimates of the size of the Roma populations differ

Share of the Roma in the total population (\%)

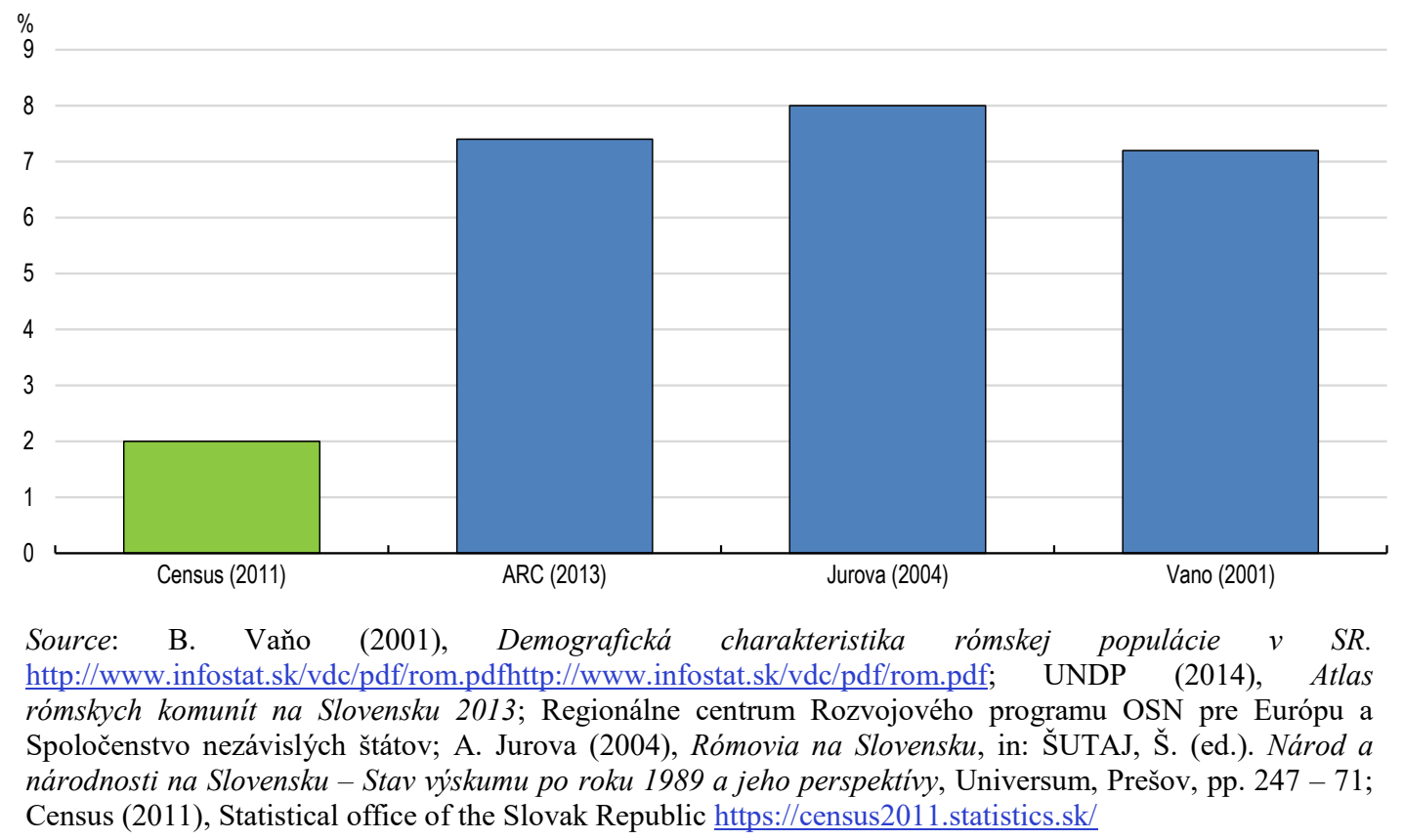

There are different available approaches and possible sources of information that can generate the data necessary for monitoring different aspects of Roma inclusion, such as field surveys or using self-identification questionnaires or through proxies such as Romalanguage proficiency. The different sources have their strengths and weaknesses; therefore it is best to use them in a complementary manner (Ivanov et al., 2015). 
The most reliable source in the Slovak Republic is the Atlas of Roma communities (ARC) in Slovakia (UNDP, 2014), which contains detailed data from the Roma communities. ARC was prepared by the Ministry of Labour, Social Affairs and Family, the UNDP Regional Centre in cooperation with the University of Prešov, the Plenipotentiary Office for Roma Communities and the Slovak Association of Towns and Municipalities. The work on ARC included field-work, which engaged approximately 30 researchers, including activists, employees of the Roma Plenipotentiary Office They visited 1070 municipalities.

Most of the data in the chapter are based on ARC and survey data, including the FRA survey in 2016 and UNDP survey in 2011. The FRA Survey are representative for Roma living in the administrative units in nine EU member states, including the Slovak Republic with density of Roma population higher than $10 \%$ and the findings reflect the situation of up to $80 \%$ of Roma living in EU Member States (FRA, 2016). Moreover, matching the administrative data with the ARC (Geva, Hidas and Machlica, 2019) provided additional findings of the situation of up to $90 \%$ of Roma living in the Slovak Republic estimated by Atlas of Roma communities 